\title{
1 Assessing the farm-scale impacts of cover crops and non-inversion 2 tillage regimes on nutrient losses from an arable catchment
}

3 Richard J. Cooper ${ }^{1}$, Zanist Hama-Aziz ${ }^{1}$, Kevin M. Hiscock ${ }^{1}$, Andrew A. Lovett ${ }^{1}$, Steve J.

4 Dugdale $^{1}$, Gisela Sünnenberg ${ }^{1}$, Lister Noble ${ }^{2}$, James Beamish $^{3}$, Poul Hovesen $^{3}$

$5{ }^{1}$ School of Environmental Sciences, University of East Anglia, Norwich Research Park, Norwich, NR4 7TJ, UK

$6 \quad{ }^{2}$ Farm Systems \& Environment, Low Road, Wortwell, Harleston, IP2O OHJ, UK

$7 \quad{ }^{3}$ Salle Farms Co. Ltd, Manor Farm, Salle, Reepham, NR10 4SF, UK

$8 \quad{ }^{*}$ Correspondence: Richard.J.Cooper@uea.ac.uk

10 Abstract

The efficacy of cover crops and non-inversion tillage regimes at minimising farm-scale nutrient losses were assessed across a large, commercial arable farm in Norfolk, UK. The trial area, covering 143 ha, was split into three blocks: winter fallow with mouldboard ploughing (Block J); shallow non-inversion tillage with a winter oilseed radish (Raphanus sativus) cover crop (Block P); and direct drilling with a winter oilseed radish cover crop (Block L). Soil, water and vegetation chemistry across the trial area were monitored over the 2012/13 (pre-trial), 2013/14 (cover crops and non-inversion tillage) and 2014/15 (non-inversion tillage only) farm years. Results revealed oilseed radish reduced nitrate $\left(\mathrm{NO}_{3}\right.$ $-\mathrm{N})$ leaching losses in soil water by $75-97 \%$ relative to the fallow block, but had no impact upon phosphorus (P) losses. Corresponding reductions in riverine $\mathrm{NO}_{3}-\mathrm{N}$ concentrations were not observed, despite the trial area covering $20 \%$ of the catchment. Mean soil $\mathrm{NO}_{3}-\mathrm{N}$ concentrations were reduced by $\sim 77 \%$ at $60-90 \mathrm{~cm}$ depth beneath the cover crop, highlighting the ability of deep rooting oilseed radish to scavenge nutrients from deep within the soil profile. Alone, direct drilling and shallow non-inversion tillage were ineffective at reducing soil water $\mathrm{NO}_{3}-\mathrm{N}$ and $\mathrm{P}$ concentrations relative to conventional ploughing. Applying starter fertiliser to the cover crop increased radish 


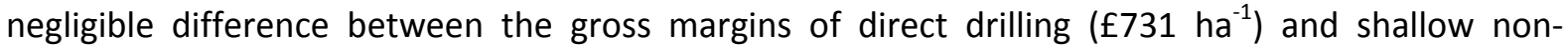
inversion tillage ( $\left.f 758 \mathrm{ha}^{-1}\right)$ with a cover crop and conventional ploughing with fallow ( $f 745 \mathrm{ha}^{-1}$ ), demonstrating farm productivity can be maintained whilst mitigating diffuse pollution. The results presented here support the wider adoption of winter oilseed radish cover crops to reduce $\mathrm{NO}_{3}-\mathrm{N}$ leaching losses in arable systems, but caution that it may take several years before catchment-scale impacts downstream are detected.

Keywords: Mitigation; Agriculture; Nitrate; Phosphorus; Conservation tillage; River;

\section{Introduction}

Diffuse nutrient pollution from intensive arable agriculture is a major driver behind the eutrophication of freshwater environments and leads to an array of detrimental economic (Dodds et al., 2009; Smith and Schindler, 2009) and environmental (Skinner et al., 1997; Némery and Garnier, 2016) impacts. As naturally limiting nutrients of plant growth in aquatic systems, the enhanced landto-river transfer of fertiliser derived nitrogen $(\mathrm{N})$ and phosphorus $(\mathrm{P})$ fuels blooms of phytoplankton, periphyton and neuro-toxin secreting cyanobacteria colonies which can dramatically lower species diversity and lead to a fundamental breakdown of ecosystem functioning (Smith et al., 1999; Hilton et al., 2006). Treating eutrophic water also incurs significant economic costs, with water companies having to remediate problems with taste, colour and odour whilst lowering concentrations of contaminants in order to make the water potable (Pretty et al., 2000). In the United Kingdom, the total costs of eutrophication have been estimated at $£ 75-114$ million per year (Pretty et al., 2003). Consequently, on-farm mitigation measures are required to help reduce land-to-river nutrient transfers, with such schemes being financially incentivised through agri-environmental stewardship programmes (Kay et al., 2009; Deasy et al., 2010).

The efficacy of two commonly applied mitigation measures at reducing nutrient losses from arable land, cover crops (Snapp et al., 2005; Tonitto et al., 2006; Valkama et al., 2015) and non-inversion 
tillage (Tebrügge and Düring, 1999; Stevens and Quinton, 2009; Soane et al., 2012), have been widely studied for several decades. Cover crops are typically non-cash crops sown in the autumn to provide winter groundcover when the field would otherwise be fallow, thereby reducing the risk of soil nutrient losses from leaching and erosion (Dabney et al., 2001; Hooker et al., 2008). A range of species can be grown, including $\mathrm{N}$ fixing leguminous (e.g. clover, vetch and pea) and non-leguminous (e.g. rye, sorghum and brassicas) varieties. Cover crops have primarily been used to minimise $\mathrm{NO}_{3}$ leaching by scavenging highly soluble residual soil $\mathrm{NO}_{3}$ and converting it into relatively immobile organic N (Aronsson and Torstensson, 1998; Beaudoin et al., 2005; Premrov et al., 2014). However, they have also been shown to protect surface soils from erosive flows, increase soil organic matter content, enhance soil structure, suppress weeds and improve soil moisture balance (Lu et al., 2000; Dabney et al., 2001; Stevens and Quinton, 2009). Unfortunately, an array of negative agronomic impacts of cover crops have also been reported and include the cost of establishment, difficulty in destroying the cover crop prior to sowing the subsequent cash crop, the harbouring of insect pests and the complexity of predicting the release of mineralised $\mathrm{N}$ as the cover crop residues degrade (Snapp et al., 2005; Deasy et al., 2010).

The main objective of non-inversion, or conservation, tillage systems is to improve soil structure and stability (Holland, 2004; Lal et al., 2007). In conventional tillage systems, the soil is typically inverted to a depth of $>20 \mathrm{~cm}$ using a mouldboard plough prior to secondary cultivation to create a seedbed into which the subsequent cash crop is sown (Morris et al., 2010). However, under non-inversion tillage systems the soil is either disturbed to a lesser degree (i.e. shallow non-inversion tillage to a depth of $<10 \mathrm{~cm}$ using discs or tines) or not disturbed at all, with sowing occurring directly into the residue of the previous crop (i.e. direct drilling) (Morris et al., 2010). By improving soil structure, non-inversion tillage methods have been shown to reduce soil erosion, increase organic matter content, improve drainage and water holding capacity and increase microbial and earthworm activity (Deasy et al., 2009; Soane et al., 2012; Abdollahi and Munkholm, 2014). However, the lack of 
surface which can be readily mobilised by surface flows and thus pose a risk to freshwater environments (Holland, 2004; Bertol et al., 2007; Stevens and Quinton, 2009).

To date, much of the research into the effectiveness of cover crops and non-inversion tillage at reducing arable nutrient losses has come from small, controlled plot scale studies (e.g. Catt et al., 1998; Bakhsh et al., 2002). Whilst such studies are typically able to yield definitive conclusions as to the effectiveness of certain measures by controlling for the multiple sources of variability that exist within agroecosystems, they are unable to demonstrate how effective these measures would be when applied in real world situations on large, commercial, arable farms. Specifically, plot-scale studies typically fail to account for the impacts of mitigation measures upon crop yields, farm profit margins, catchment-scale nutrient losses, or the practicalities for the farmer of deploying such measures. Consequently, there is a need for more farm- and catchment-scale approaches to help better inform government decision making on agri-environmental policy, particularly in the UK (Kay et al., 2009). Addressing this deficiency, in 2010 the UK government launched the Demonstration Test Catchment (DTC) research platform to evaluate the extent to which on-farm mitigation measures could cost-effectively reduce the impacts of diffuse agricultural pollution on river ecology whilst maintaining food production capacity (McGonigle et al., 2014). Across the UK, three DTCs were established with each concentrating on a different farming system. This paper focuses upon the intensive arable River Wensum DTC in Norfolk, UK, where cover crops and non-inversion tillage methods were trialled as diffuse pollution mitigation measures on a large, commercial arable farm over a three-year period (Wensum Alliance, 2016).

The primary objectives of this paper are as follows:

(i) To assess the effectiveness of cover crops and non-inversion tillage regimes at reducing $\mathrm{N}$ and $\mathrm{P}$ losses at the farm-scale;

(ii) To examine the impact of cover crops and non-inversion tillage methods on soil fertility; 
(iii) To assess the sub-catchment scale impacts of the mitigation measures by monitoring river water chemistry downstream of the trial area;

(iv) To compare the economic viability and farm practicalities of cover crops and non-inversion tillage operations with those of conventional farm practice.

\section{Methods}

\subsection{Study location}

This study focuses upon the large $\left(20 \mathrm{~km}^{2}\right)$ commercial Salle Park Estate located within the Blackwater sub-catchment of the lowland calcareous River Wensum, Norfolk, UK $\left(52^{\circ} 47^{\prime} 09^{\prime \prime} \mathrm{N}\right.$, $\left.01^{\circ} 07^{\prime} 00^{\prime \prime} \mathrm{E}\right)$. The estate is situated $40-50 \mathrm{~m}$ above sea level with gentle slopes $\left(<1^{\circ}\right)$ meaning that subsurface leaching rather than surface runoff is the dominant pollution pathway. Intensive arable cropping comprises $79 \%$ of the land use and is managed with a seven-year rotation of winter wheat, winter and spring barley, winter oilseed rape, spring beans and sugar beet. The estate also includes $15 \%$ improved grassland, $5 \%$ mixed woodland and $1 \%$ rural settlements. Surface soils are predominantly clay loam to sandy clay loam ( $<0.5 \mathrm{~m}$ depth) and these are underlain by Quaternary deposits of chalky, flint-rich boulder clays and glaciofluvial and glaciolacustrine sands and gravels (0.5-20 m). The bedrock is Cretaceous white chalk (>20 m) (Hiscock et al., 1993; Lewis, 2011). River channels draining the catchment have been extensively deepened and straightened to reduce water residence times resulting in the river no longer connecting to its floodplain. The site experiences a temperate maritime climate, with a mean annual temperature of $10.1^{\circ} \mathrm{C}$ and a mean annual rainfall total of $674 \mathrm{~mm} \mathrm{y}^{-1}$ (1981-2010) (Meteorological Office, 2016). Farm year (September to August) precipitation totals were $624 \mathrm{~mm}$ (2012/13), $759 \mathrm{~mm} \mathrm{(2013/14)} \mathrm{and} 683 \mathrm{~mm} \mathrm{(2014/15)} \mathrm{during} \mathrm{this}$ study.

\subsection{Cultivation methods}


In 2013, 143 ha of arable land was identified for the trialling of winter cover crops and non-inversion tillage practices aimed at reducing diffuse nutrient losses into the River Blackwater (Figure 1; Table 1). This consisted of nine fields split into three mitigation measures blocks, with each block sown with the same crop and the same fertiliser application rate during the 2013/14 (spring beans; $0 \mathrm{~kg} \mathrm{~N}$ $\mathrm{ha}^{-1}, 30 \mathrm{~kg} \mathrm{P} \mathrm{ha}^{-1}, 55 \mathrm{~kg} \mathrm{~K} \mathrm{ha}^{-1}$ ) and 2014/15 (winter wheat; $220 \mathrm{~kg} \mathrm{~N} \mathrm{ha}^{-1}, 22 \mathrm{~kg} \mathrm{P} \mathrm{ha}^{-1}, 85 \mathrm{~kg} \mathrm{~K} \mathrm{ha}^{-1}$ ) farm years. Block J (two fields, 42 ha) was kept as a control and was cultivated by conventional mouldboard ploughing to $25 \mathrm{~cm}$ depth prior to sowing. Block P (three fields, 52 ha) underwent shallow non-inversion tillage to a depth of $10 \mathrm{~cm}$ using a Väderstad Carrier and Topdown cultivator prior to sowing with a Rapid drill. Block L (four fields, 53 ha) was direct drilled into the previous crop that all blocks would have had comparable fertiliser inputs.

In addition to the different tillage regimes, Blocks $\mathrm{L}$ and $\mathrm{P}$ were sown with an oilseed radish August 2013 (Figure 2). The radish was sprayed with herbicide (glyphosate) in mid-January 2014 to kill it prior to establishment of the spring beans. Oilseed radish was chosen because it provides good winter groundcover and has extensive, deep tap roots to help loosen compacted soil and scavenge nutrients at depth. Since there was some debate among local agronomists about the merits of applying a starter fertiliser to cover crops, this was evaluated by applying $30 \mathrm{~kg} \mathrm{~N} \mathrm{ha}^{-1}$ to five of the fields whilst the other two received no fertiliser. In addition to the three mitigation measures blocks, Block N (two fields, 63 ha), being managed by normal farm practice but with different crop rotations, was also monitored to facilitate comparison with the trial area. The efficacy of the cover crops and non-inversion tillage regimes at reducing $\mathrm{N}$ and $\mathrm{P}$ losses was assessed by monitoring soil, water and vegetation chemistry across the study area during three September to August farm years: 

tillage only).

\subsection{Field installations and sample collection}

152

\subsubsection{Porous pots}

Nine sets of porous pots were installed across the mitigation measure blocks in late 2013 to facilitate soil water sampling, with three sets installed in each of Blocks J, L and P (Figure 1). Locations within each block were selected to incorporate the full range of soil textures. Each set consisted of ten individual pots installed in a row $1 \mathrm{~m}$ apart and buried to $90 \mathrm{~cm}$ depth. Soil water was collected on five occasions during the study period (February, April and May 2014, March and May 2015). On each occasion, pots were placed under vacuum to evacuate and dispose of any residual water and were then left under vacuum for $4-5 \mathrm{~h}$ to draw in a fresh sample of soil water. Recovered volumes from each pot were typically $20-50 \mathrm{~mL}$, although five of the nine sets yielded no sample in May 2014. Where volumes were $<10 \mathrm{~mL}$, individual samples were bulked together to provide sufficient water for analysis.

\subsubsection{Field drains}

Most of the arable land in the Salle Park Estate is extensively under-drained by a dense network of clay and plastic field drains installed at $100-150 \mathrm{~cm}$ depth and which discharge into the River Blackwater at a density of 43 outflows per km. Highest recorded discharges were $>10 \mathrm{~L} \mathrm{~s}^{-1}$, although discharge varied depending upon season, drain depth, catchment area and antecedent moisture conditions. Most drains dried up entirely between June and September. Of 125 drains identified, a subset of 11 was selected for routine monitoring at 1-2 week intervals between March 2013 and March 2015 (Figure 1). Two drains drained the control Block J (D08L, D10L), three Block L (D02L, D04L, D06L), three Block P (D01R, D03R, D16R) and three Block N (D07R, D09R, D13L). On each 
sampling occasion, a $1 \mathrm{~L}$ grab sample was collected from the drain outflow and the discharge $\left(\mathrm{L} \mathrm{s}^{-1}\right)$ recorded.

Soils in Blocks J, P and L were sampled on five occasions during the study. Samples were collected from four locations within each individual field, with the locations selected to capture the full range of textural variability (Figure 1). On the first two sampling occasions (September 2013 and February 2014), a powered hydraulic Hydrocare auger collected $90 \mathrm{~cm}$ depth soil cores in two concentric circles at 12 points within $10 \mathrm{~m}$ of each sampling location. The cores were then divided into three depths $(0-30 \mathrm{~cm}, 30-60 \mathrm{~cm}, 60-90 \mathrm{~cm})$ and the soils combined to produce a single bulked sample ( $250 \mathrm{~g})$ for each depth at each location. In total, 108 bulked soil samples were collected on each sampling occasion (i.e. 9 fields $\times 4$ locations $\times 3$ depths). On the following three occasions (July 2014, February 2015 and July 2015) sampling was restricted to the topsoil layer (0-15 cm depth) with soil collected from 12 points within $2 \mathrm{~m}$ of the sampling location using a hand operated Dutch auger. Again, these 12 samples were combined to produce one bulked soil for each sampling location. In total, 36 samples were collected on each of these sampling occasions (i.e. 9 fields $x 4$ locations). All soil samples were placed into air-tight polyethylene bags and stored in cool boxes prior to analysis.

\subsubsection{Vegetation}

To assess cover crop nutrient uptake rates, in January 2014 oilseed radish samples were collected from the same locations within Blocks $L$ and $P$ as the soil samples. Within a $0.25 \mathrm{~m}^{2}$ quadrat at each location, all oilseed radish plants were dug up and the leaf and root material separated for individual analysis. A combined root and leaf fresh weight of $\sim 700 \mathrm{~g}$ was collected at each location. Cover crop samples were differentiated by fields with or without a starter fertiliser application (Table 1).

\subsubsection{Riverine bankside monitoring}


To assess the impact of the mitigation measures on nutrient concentrations in the River Blackwater, an automated bankside monitoring kiosk $650 \mathrm{~m}$ downstream of the trial area analysed a range of water quality parameters at 30-min resolution throughout the study period (September 2012 August 2015). $\mathrm{NO}_{3}-\mathrm{N}$ concentrations were measured by a Hach Lange Nitratax SC optical probe, whilst total reactive phosphorus (TRP) and total phosphorus (TP) concentrations were measured by a Hach Lange Sigmatax SC coupled with a Phosphax Sigma. Stream stage was determined by a pressure transducer housed in a stilling well and was converted to discharge using a manual stagedischarge rating curve. Further details are provided in Outram et al. (2014).

\subsection{Laboratory analysis}

\subsubsection{Water samples}

Field drain and porous pot $\mathrm{NO}_{3}-\mathrm{N}$ concentrations were determined by ion chromatography using a Dionex ICS-2000. A sodium nitrate $\left(\mathrm{NaNO}_{3}\right)$ standard $\left(0.50-7.50 \mathrm{mg} \mathrm{\textrm {L } ^ { - 1 }}\right)$ was used for calibration. Instrument accuracy $\left(<0.2 \mathrm{mg} \mathrm{L}^{-1}\right)$ was determined by analysing a certified reference material $\left(\mathrm{NO}_{3}{ }^{-}=\right.$ $\left.214 \mu \mathrm{mol} \mathrm{L}{ }^{-1}\right)$ with each sample batch. Phosphate $\left(\mathrm{PO}_{4}-\mathrm{P}\right)$ and TP concentrations were determined colorimetrically (molybdate) using a Skalar SAN++ continuous flow analyser. A potassium dihydrogen orthophosphate standard $\left(\mathrm{KH}_{2} \mathrm{PO}_{4} ; 10-500 \mu \mathrm{g} \mathrm{L}{ }^{-1}\right)$ was used for calibration. Instrument accuracy for $\mathrm{PO}_{4}-\mathrm{P}\left(<7.8 \mu \mathrm{g} \mathrm{L}^{-1}\right)$ and TP $\left(<9.8 \mu \mathrm{g} \mathrm{L}^{-1}\right)$ were determined by analysis of certified reference materials $(\mathrm{P}$

$212=78.0-97.4 \mu \mathrm{g} \mathrm{L}^{-1}$ ) with each batch.

\subsubsection{Soil samples}

214 All soil samples were chopped, mixed and sieved to $2 \mathrm{~mm}$. Soil $\mathrm{NO}_{3}-\mathrm{N}$ concentrations were determined colorimetrically after shaking a fresh portion of each sample with 2 mol potassium chloride $(\mathrm{KCl})$ to extract the mineral $\mathrm{N}$ fractions and reacting with sulphanilamide $\left(\mathrm{C}_{6} \mathrm{H}_{8} \mathrm{~N}_{2} \mathrm{O}_{2} \mathrm{~S}\right)$ and $n$ -

217 (1-Naphthyl)ethylenediamine $\left(\mathrm{C}_{12} \mathrm{H}_{14} \mathrm{~N}_{2}\right)$. Olsen's available $\mathrm{P}$ was also determined colorimetrically 218 after shaking a portion of air-dried soil with $0.5 \mathrm{~mol}$ sodium bicarbonate $\left(\mathrm{NaHCO}_{3}\right)$ solution and 
adding ammonium heptamolybdate $\left(\left(\mathrm{NH}_{4}\right)_{6} \mathrm{Mo}_{7} \mathrm{O}_{24}\right)$ and ascorbic acid $\left(\mathrm{C}_{6} \mathrm{H}_{8} \mathrm{O}_{6}\right)$. Soil potassium (K) concentrations were determined by flame photometry after shaking the soil with ammonium nitrate $\left(\mathrm{NH}_{4} \mathrm{NO}_{3}\right)$ to extract available $\mathrm{K}$. Soil organic matter (SOM) content was determined by loss-onignition $\left(430^{\circ} \mathrm{C}\right)$.

\subsubsection{Cover crop samples}

224 Cover crop leaf and root material was separated, air-dried, ground and sieved to $0.5 \mathrm{~mm}$. On representative portions of each, the total nitrogen (TN) content was determined by chromatography using the Dumas method (Bremner, 1965). TP contents were determined by inductively coupled plasma optical emission spectroscopy (ICP-OES) after first digesting material in nitric $\left(\mathrm{HNO}_{3}\right)$ and hydrochloric $(\mathrm{HCl})$ acids using a temperature controlled digestion block.

\section{Results}

\subsection{Impacts of mitigation measures on soil water}

\subsubsection{Nitrate}

During the pre-trial period (2012/13) when all blocks were under either winter wheat or spring barley, there were no significant differences in mean field drain $\mathrm{NO}_{3}-\mathrm{N}$ concentration between Blocks L (5.5 $\left.\mathrm{mg} \mathrm{N} \mathrm{L}^{-1}\right), \mathrm{P}\left(6.4 \mathrm{mg} \mathrm{N} \mathrm{L}^{-1}\right)$ and J $\left(9.6 \mathrm{mg} \mathrm{N} \mathrm{L}^{-1}\right)$ (Figure 3; Table 2). Concentrations of 10.0 $\mathrm{mg} \mathrm{N} \mathrm{L}^{-1}$ were observed in the normal practice Block $\mathrm{N}$, with the two fields in this block under winter barley and spring beans.

However, during the cover crop and non-inversion tillage period (2013/14), pronounced contrasts in soil water $\mathrm{NO}_{3}-\mathrm{N}$ concentrations were recorded between blocks with or without a cover crop (Figure 3; Table 2). Mean field drain $\mathrm{NO}_{3}-\mathrm{N}$ concentrations in cover crop Blocks $\mathrm{P}\left(3.5 \mathrm{mg} \mathrm{N} \mathrm{L}^{-1}\right)$ and L (1.8 mg $\left.\mathrm{N} \mathrm{L}^{-1}\right)$ were significantly $(p<0.05)$ smaller than the ploughed fallow control Block J $\left(14.0 \mathrm{mg} \mathrm{N} \mathrm{L}^{-1}\right)$.

241 This pronounced contrast was even more apparent in the porous pot samples (Figure 4), where mean soil water $\mathrm{NO}_{3}-\mathrm{N}$ concentrations in Blocks $\mathrm{P}$ and $\mathrm{L}$ were $96-97 \%$ lower than Block J during 

concentrations ( $37.4 \mathrm{mg} \mathrm{N} \mathrm{L}^{-1}$ ) in late May 2014 coincided with a period of increased rainfall and thus increased $\mathrm{NO}_{3}-\mathrm{N}$ leaching. However, an increase in mean porous pot $\mathrm{NO}_{3}-\mathrm{N}$ concentration in Block $\mathrm{L}$ (15.5 $\mathrm{mg} \mathrm{N} \mathrm{L}^{-1}$ ) during the same period may also reflect $\mathrm{NO}_{3}-\mathrm{N}$ release during mineralisation of the cover crop residues (Figure 4). In Block N, $\mathrm{NO}_{3}-\mathrm{N}$ concentrations were high in the two drains (D07R, D13L) discharging underneath a field of winter wheat in autumn 2013 ( $>10 \mathrm{mg} \mathrm{N} \mathrm{L}^{-1}$ ), but steadily declined throughout the winter to $\sim 4 \mathrm{mg} \mathrm{N} \mathrm{L}^{-1}$ by March 2014. The other drain in Block N (D09R) under winter oilseed rape performed similarly to the cover crop blocks, with low $\mathrm{NO}_{3}-\mathrm{N}$ concentrations (mean $2.9 \mathrm{mg} \mathrm{N} \mathrm{L}^{-1}$ ) throughout winter 2013/14.

During the non-inversion tillage only period (2014/15), there were no significant $(p>0.05)$ differences in field drain $\mathrm{NO}_{3}-\mathrm{N}$ concentrations between any of the blocks. Mean concentrations recorded under shallow non-inversion tillage $\left(5.5 \mathrm{mg} \mathrm{N} \mathrm{L}^{-1}\right)$ and direct drill $\left(6.2 \mathrm{mg} \mathrm{N} \mathrm{L}^{-1}\right)$ regimes were very similar to that recorded in the ploughed Block J $\left(4.3 \mathrm{mg} \mathrm{N} \mathrm{L}^{-1}\right)$. Similarly, there were no significant or consistent differences in the $\mathrm{NO}_{3}-\mathrm{N}$ concentrations recorded in the porous pots of the three blocks during March or May 2015.

\subsubsection{Phosphorus}

In contrast to $\mathrm{NO}_{3}-\mathrm{N}$, there were no significant $(p>0.05)$ differences in soil water TP or $\mathrm{PO}_{4}-\mathrm{P}$ concentrations between the different cover crop and cultivation blocks in either the field drains or the porous pots (Figures 3 and 4; Table 2). During the pre-trial period (2012/13), mean field drain TP concentrations ranged from $16 \mu \mathrm{g} \mathrm{L}^{-1}$ in Block $N$ to $26 \mu \mathrm{g} \mathrm{L}^{-1}$ in Block J, although differences were not significant due to large variability within each block. Similarly, during the cover crop period (2013/14) mean field drain TP concentrations in Blocks $P\left(14 \mu \mathrm{g} \mathrm{L}^{-1}\right)$ and $\mathrm{L}\left(16 \mu \mathrm{g} \mathrm{L}^{-1}\right)$ with a cover crop were very similar to the control Block $\mathrm{J}\left(15 \mu \mathrm{g} \mathrm{L}^{-1}\right)$ and normal practice Block $\mathrm{N}\left(17 \mu \mathrm{g} \mathrm{L}^{-1}\right)$. During the same period, mean $\mathrm{PO}_{4}-\mathrm{P}$ concentrations in the porous pots ranged from $31-67 \mu \mathrm{g} \mathrm{L}^{-1}$ in the cover crop Blocks $\mathrm{L}$ and $\mathrm{P}$ to $42-54 \mu \mathrm{g} \mathrm{L}^{-1}$ in the control Block J, although large variability within 
each block again meant differences were not significant (Figure 4). During the non-inversion tillage only period (2014/15), mean field drain TP concentrations in the shallow non-inversion tillage Block $\mathrm{P}\left(14 \mu \mathrm{g} \mathrm{L}{ }^{-1}\right)$ were very similar to that recorded in the direct drill Block $\mathrm{L}\left(15 \mu \mathrm{g} \mathrm{L^{-1 }}\right)$, the control Block

$\mathrm{J}\left(16 \mu \mathrm{g} \mathrm{L}^{-1}\right)$ and the normal practice Block $\mathrm{N}\left(11 \mu \mathrm{g} \mathrm{L^{-1 }}\right)$. Mean porous pot $\mathrm{PO}_{4}-\mathrm{P}$ concentrations in March 2015 were larger in Block $\mathrm{P}\left(55 \mu \mathrm{g} \mathrm{L}^{-1}\right)$ than Block J $\left(24 \mu \mathrm{g} \mathrm{L}^{-1}\right)$, but differences were not significant.

\subsection{Impacts of mitigation measures on soil nutrients}

\subsubsection{Nitrate- $N$}

There were no significant differences $(p>0.05)$ in topsoil $\mathrm{NO}_{3}-\mathrm{N}$ concentrations between the three mitigation blocks during any of the five sampling occasions (Figure 5a; Table 3). High mean soil $\mathrm{NO}_{3}-$ $\mathrm{N}$ concentrations $\left(32.3-37.3 \mathrm{~kg} \mathrm{~N} \mathrm{ha}^{-1}\right)$ were recorded in all blocks during the pre-trial period in September 2013 due to residual $\mathrm{NO}_{3}-\mathrm{N}$ remaining from the previous crop. Similarly, mean concentrations in all blocks tended to be lower in February $2015\left(1.6-3.4 \mathrm{~kg} \mathrm{~N} \mathrm{ha}^{-1}\right)$ than in July 2015 (5.6-10.3 $\mathrm{kg} \mathrm{N} \mathrm{ha}^{-1}$ ), likely indicating both the increased leaching of soil $\mathrm{NO}_{3}-\mathrm{N}$ during the winter and the accumulation of applied $\mathrm{NO}_{3}-\mathrm{N}$ in the topsoil over the course of the farm year. However, despite the lack of contrast in topsoil $\mathrm{NO}_{3}-\mathrm{N}$ between blocks, there were significant reductions in concentration at depth beneath the cover crop and non-inversion tillage blocks in February 2014 (Figure $5 b$ ). In both Blocks $\mathrm{L}$ and $\mathrm{P}$, mean soil $\mathrm{NO}_{3}-\mathrm{N}$ concentrations were reduced by $35-37 \%$ at $30-$ $60 \mathrm{~cm}$ depth and by $76-77 \%$ at $60-90 \mathrm{~cm}$ depth relative to control Block J.

\subsubsection{Phosphorus}

Topsoil P concentrations were significantly $(p<0.05)$ greater in Blocks $L$ and $\mathrm{P}$ than in Block J during the cover crop and non-inversion tillage period (Table 3). However, mean concentrations in Blocks L $\left(142.5 \mathrm{~kg} \mathrm{P} \mathrm{ha}^{-1}\right)$ and $\mathrm{P}\left(132.0 \mathrm{~kg} \mathrm{P} \mathrm{ha}^{-1}\right)$ were also significantly greater than Block J (96.4 kg P ha $\left.{ }^{-1}\right)$ during the pre-trial period, thus indicating these contrasts more likely reflect pre-existing differences 
in soil type rather than the impacts of the mitigation measures. There were no significant differences between Block $L$ and Block $P$ during any of the five sampling rounds.

\subsubsection{Potassium}

Mean topsoil K concentrations were significantly $(p<0.05)$ greater in Blocks L $\left(292\right.$ and $\left.648 \mathrm{~kg} \mathrm{~K} \mathrm{ha}^{-1}\right)$ and $\mathrm{P}\left(250\right.$ and $\left.687 \mathrm{~kg} \mathrm{~K} \mathrm{ha}^{-1}\right)$ than in Block J (193 and $\left.427 \mathrm{~kg} \mathrm{~K} \mathrm{ha}^{-1}\right)$ during both the cover crop and non-inversion tillage only periods, respectively (Table 3 ). With no significant difference between Block J and Blocks L and P in September 2013, these results indicate that covers crops and noninversion tillage were likely responsible for the increased topsoil $\mathrm{K}$ concentrations observed during the trial period. Concentrations in the direct drill Block $L$ were marginally higher than the shallow non-inversion tillage Block P during February and July 2015, although due to large variability these differences were not significant.

\subsubsection{Organic matter}

There were no significant $(p>0.05)$ differences in SOM content between the three blocks during any of the five sampling occasions, with mean SOM concentrations in Block J (2.0-2.1\%) always greater than Blocks P (1.7-1.9\%) and L (1.5-1.8\%) (Table 3). The similarity of SOM content in Blocks L and P during February and July 2015 also indicated no measurable difference between direct drill and shallow non-inversion tillage options. However, there was evidence of a small increase in the mean SOM content of Blocks $\mathrm{L}$ and $\mathrm{P}$ over the 22-month study period, with relative concentrations increasing by 20\% and 12\%, respectively, between September 2013 and July 2015 .

\subsection{Impacts of mitigation measures on river water quality}

In pronounced contrast to the field drain and porous pot data, Figure 6 reveals there was no corresponding reduction in riverine $\mathrm{NO}_{3}-\mathrm{N}$ concentrations during the cover crop and non-inversion tillage period. Mean $\mathrm{NO}_{3}-\mathrm{N}$ concentrations in the River Blackwater varied from $6.8 \mathrm{mg} \mathrm{N} \mathrm{L}^{-1}$ (range $=$ 
$3153.0-12.8 \mathrm{mg} \mathrm{N} \mathrm{L}^{-1}$; st. dev. $=2.3 \mathrm{mg} \mathrm{N} \mathrm{L}^{-1}$ ) during the 2012/13 farm year, to $7.4 \mathrm{mg} \mathrm{N} \mathrm{L}^{-1}$ (range $=2.1-$ 17.5 $\mathrm{mg} \mathrm{N} \mathrm{L}^{-1}$; st. dev. $=2.9 \mathrm{mg} \mathrm{N} \mathrm{L}^{-1}$ ) during $2013 / 14$ and $6.0 \mathrm{mg} \mathrm{N} \mathrm{L}^{-1}$ (range $=0.5-18.8 \mathrm{mg} \mathrm{N} \mathrm{L}^{-1}$; st. dev. $=2.2 \mathrm{mg} \mathrm{N} \mathrm{L}{ }^{-1}$ ) during 2014/15. Periods of elevated $\mathrm{NO}_{3}-\mathrm{N}$ concentration predominantly corresponded with periods of greater stream discharge, with higher concentrations observed during the winter months (November - March) and during heavy rainfall events (e.g. late May 2014). However, the highest concentrations $\left(>15 \mathrm{mg} \mathrm{N} \mathrm{L}^{-1}\right.$ ) recorded in May, June and October 2014 could also partly relate to the mineralisation of the cover crop residues releasing a flush of $\mathrm{NO}_{3}-\mathrm{N}$, especially as increases in Block $\mathrm{L}$ porous pot $\mathrm{NO}_{3}-\mathrm{N}$ concentrations were also recorded at this time. Riverine $\mathrm{NO}_{3}-\mathrm{N}$ concentrations exceeded the $11.3 \mathrm{mg} \mathrm{N} \mathrm{L}^{-1}$ EU Drinking Water Directive (98/83/EC) standard 4.5\% of the time between September 2012 and August 2015.

For TP, mean concentrations were observed to decline over the study period, from $93 \mu \mathrm{g} \mathrm{PL}^{-1}$ (range $=41-1000 \mu \mathrm{g} \mathrm{P} \mathrm{L}{ }^{-1}$; st. dev. $=49 \mu \mathrm{g} \mathrm{P} \mathrm{L}^{-1}$ ) during $2012 / 13$, to $78 \mu \mathrm{g} \mathrm{PL}^{-1}$ (range $=38-1000 \mu \mathrm{g} \mathrm{P} \mathrm{L}{ }^{-1}$; st. dev. $=43 \mu \mathrm{g} \mathrm{P} \mathrm{L}^{-1}$ ) during 2013/14 and to $66 \mu \mathrm{g} \mathrm{L}^{-1}$ (range $=34-1000 \mu \mathrm{g} \mathrm{P} \mathrm{L}^{-1}$; st. dev. $=39 \mu \mathrm{g} \mathrm{L} \mathrm{L}^{-1}$ ) in 2014/15. These declines in instream TP concentrations arose despite the absence of similar such declines in TP and $\mathrm{PO}_{4}-\mathrm{P}$ concentrations of field drains and porous pots, respectively, indicating the mitigation measures are unlikely to have been the dominant casual factor. Large peaks in TP concentration (>200 $\mathrm{g} \mathrm{P} \mathrm{L}^{-1}$ ) were almost exclusively associated with heavy precipitation events.

\subsection{Impacts of applying starter fertiliser}

Nutrient analysis of the oilseed radish cover crop revealed there was a significant difference $(p<$ $0.05)$ in the mean $\mathrm{N}$ uptake between cover crops grown with $\left(79.4 \mathrm{~kg} \mathrm{~N} \mathrm{ha}^{-1}\right)$ or without $(69.6 \mathrm{~kg} \mathrm{~N}$ $\mathrm{ha}^{-1}$ ) a starter fertiliser (Table 4). This was due to a combination of both greater dry matter production in fields with $\left(2.8 \mathrm{t} \mathrm{ha}^{-1}\right)$ rather than without $\left(2.6 \mathrm{t} \mathrm{ha}^{-1}\right)$ a starter fertiliser, and because the combined mean $\mathrm{N}$ content of root and leaf material was greater in the five fields where the fertiliser was applied (2.85\%) than in the two fields where it was omitted (2.63\%). Despite this, mean $\mathrm{NO}_{3}$ concentrations recorded in the porous pots during February 2014 were significantly higher in 
the fertilised fields $\left(0.8 \mathrm{mg} \mathrm{NO}_{3}-\mathrm{N} \mathrm{L}^{-1}\right)$ compared to the unfertilised fields $\left(0.3 \mathrm{mg} \mathrm{NO}{ }_{3}-\mathrm{N} \mathrm{L}^{-1}\right)$. The uptake of K was significantly $(p<0.05)$ greater in fields with $\left(90.0 \mathrm{~kg} \mathrm{~K} \mathrm{ha}^{-1}\right)$ rather than without $(76.8$ $\mathrm{kg} \mathrm{K} \mathrm{ha} \mathrm{K}^{-1}$ ) a starter fertiliser application. However, $\mathrm{P}$ uptake was not influenced by fertiliser application, with both treatments yielding mean uptake rates of $11.5 \mathrm{~kg} \mathrm{P} \mathrm{ha}^{-1}$.

\section{Discussion}

\subsection{Effectiveness of the cover crop}

The oilseed radish cover crop proved to be highly effective at reducing soil water $\mathrm{NO}_{3}-\mathrm{N}$ levels, thereby minimising $\mathrm{NO}_{3}-\mathrm{N}$ leaching losses and lowering diffuse pollution risk. Concentrations in the $90 \mathrm{~cm}$ depth porous pots were reduced by $96-97 \%$ in late winter (February 2014 ) and by $79-80 \%$ in mid-spring (April 2014) compared to the fallow control block, whilst concentrations were reduced by $75-87 \%$ in the $100-150 \mathrm{~cm}$ depth field drains across the $2013 / 14$ farm year. This beneficial effect compares favourably with a range of previously reported $\mathrm{NO}_{3}-\mathrm{N}$ reductions under cover crops of $40-$ 50\% (Aronsson and Torstensson, 1998), 38-70\% (Hooker et al., 2008), 0-98\% (Stevens and Quinton, 2009) and 25-60\% (Valkama et al., 2015). Importantly, soil water $\mathrm{NO}_{3}-\mathrm{N}$ concentrations under the cover crop blocks were consistently below the EU Drinking Water Directive (98/83/EC) standard of $11.3 \mathrm{mg} \mathrm{N} \mathrm{L}^{-1}$, whilst concentrations under the fallow block were above this standard for $\sim 88 \%$ of the 2013/14 farm year.

The substantial reductions in soil $\mathrm{NO}_{3}-\mathrm{N}$ at $60-90 \mathrm{~cm}$ depth highlight that deep rooting oilseed radish is capable of scavenging $\mathrm{N}$ from deeper within the soil profile than likely would be possible by shallower rooting cover crop varieties (e.g. rye grass). Interestingly, the significantly reduced $\mathrm{NO}_{3}-\mathrm{N}$ concentrations recorded in field drain D09R during 2013/14 reveals that winter sown oilseed rape had a similar performance as the oilseed radish in absorbing residual soil $\mathrm{NO}_{3}-\mathrm{N}$ and thus reducing leaching risk, an observation also reported in other studies (Catt et al. 1998; Macdonald et al., 2005). 
This finding suggests that it is the establishment of actively growing groundcover early in the autumn which is central to minimising $\mathrm{NO}_{3}-\mathrm{N}$ leaching losses.

The cover crop did not have any significant impact upon P concentrations in either soil or soil water, a finding consistent with previous studies (Abdollahi and Munkholm, 2014). This result is not surprising given that leaching, rather than surface runoff, is considered the dominant nutrient loss pathway in this catchment and $\mathrm{P}$ has substantially lower mobility in soil than $\mathrm{N}$ due to sorption onto metal oxyhydroxides. Soil K concentrations were, however, significantly impacted, with mean concentrations increasing by $12-26 \%$ in the cover crop blocks between September 2013 and February 2014 , compared to a $14 \%$ decline observed in the control block. This increase in topsoil fertility can in part be explained by the cover crop providing both winter groundcover to reduce leaching losses and a source of organic matter for mineralisation at the soil surface.

\subsection{Effectiveness of non-inversion tillage}

Non-inversion tillage alone was ineffective at reducing soil water $\mathrm{NO}_{3}-\mathrm{N}$ concentrations during the 2014/15 farm year, with neither direct drilling nor shallow non-inversion tillage significantly reducing concentrations compared to the control or normal practice blocks. In fact, between October 2014 and March 2015, field drain $\mathrm{NO}_{3}-\mathrm{N}$ concentrations in the direct drill Block $\mathrm{L}$ exceeded the drinking water standard (11.3 $\mathrm{mg} \mathrm{N} \mathrm{L}^{-1}$ ) on $14 \%$ of sampling occasions, compared to $3 \%$ under the control Block $\mathrm{J}$ and $2 \%$ under shallow non-inversion tillage (Block P). This is broadly consistent with the findings of previous studies which reported no clear differences in $\mathrm{NO}_{3}-\mathrm{N}$ leaching losses between conventional and non-inversion tillage practices (Stevens and Quinton, 2009; Soane et al., 2012; Premrov et al., 2014). The effectiveness of non-inversion tillage at minimising $\mathrm{NO}_{3}-\mathrm{N}$ leaching tends to vary depending upon soil type, infiltration pathways and mineralisation rates of crop residues (Soane et al., 2012). Leaching losses of $P$ were also not decreased by either non-inversion cultivation regime relative to the control or normal practice blocks. Previous studies have reported reductions in surface runoff losses of TP under shallow non-inversion cultivation (e.g. Deasy et al., 2009), 
however low topographic gradients in the Blackwater catchment provide limited opportunity for the initiation of surface runoff. Overall, the results presented here indicate that when employed alone, neither direct drilling nor shallow non-inversion tillage are effective at reducing nutrient leaching losses from arable land.

Nevertheless, the increase in soil K levels does indicate a general improvement in soil nutrient status over the duration of the study, particularly in the direct drilled Block L where mean concentrations were $26-53 \%$ higher during $2013 / 14$ and $2014 / 15$ than those recorded during the $2012 / 13$ pre-trial period. Such increases in topsoil K concentrations under non-inversion systems have been widely reported in the literature (Dabney et al., 2001; Bertol et al., 2007; Abdollahi and Munkholm, 2014) and been attributed to the accumulation of crop residues on the soil surface. Similarly, whilst not statistically significant, the mean SOM content showed a relative increase of $20 \%$ under direct drill and $12 \%$ under shallow non-inversion tillage over the study period, compared with a $5 \%$ increase in the control block. Considering that topsoil organic carbon contents across the River Blackwater catchment are widely $<2 \%$ (Rawlins et al., 2013), any increase in organic matter arising from employing non-inversion tillage systems could ultimately yield considerable benefits in terms of both soil fertility and soil structural stability (Puget and Lal, 2005). Given this was a relatively short twoyear study, the results presented here are encouraging considering that previous research has demonstrated it can take many years of employing non-inversion tillage and/or cover crop systems before substantial improvements in soil carbon content and nutrient availability are achieved (Thomsen and Christensen, 2004). Further study to determine longer-term changes in SOM content would be beneficial.

\subsection{Nitrogen balance}

411 The application of starter $\mathrm{N}$ fertiliser to five fields of oilseed radish cover crop in August 2013 412 increased the mean $\mathrm{N}$ uptake rate of the cover crop by $9.8 \mathrm{~kg} \mathrm{~N} \mathrm{ha}^{-1}$ relative to the two unfertilised 413 fields, primarily due to an increase in biomass. However, this enhanced uptake by the cover crop 
was smaller than the fertiliser application rate $\left(30 \mathrm{~kg} \mathrm{~N} \mathrm{ha}^{-1}\right)$, leading to a net accumulation of $\mathrm{N}$ of $20.2 \mathrm{~kg} \mathrm{~N} \mathrm{ha}^{-1}$ within the fertilised fields. Evidence of this accumulation can be seen in the soil $\mathrm{N}$ contents at 0-30, 30-60 and 60-90 cm depths which were 3.6, 3.1 and $1.0 \mathrm{~kg} \mathrm{NO}_{3}-\mathrm{N} \mathrm{ha}{ }^{-1}$ greater in the fields where fertiliser was applied compared to those without (Table 5). Likewise, mean $\mathrm{NO}_{3}$ leaching losses recorded in the porous pots in February 2014 were also significantly higher in the fields with fertiliser applied $\left(0.8 \mathrm{mg} \mathrm{NO}_{3}-\mathrm{N} \mathrm{L}^{-1}\right)$ compared to those without $\left(0.3 \mathrm{mg} \mathrm{NO}_{3}-\mathrm{N} \mathrm{L}^{-1}\right)$. These results confirm that, under these conditions, the application of starter fertiliser to the cover crop was detrimental to the objective of reducing nutrient leaching. However, the efficacy of a cover crop in reducing leaching depends upon its early establishment prior to the wetting up of the catchment in the autumn (Dabney et al., 2001). Therefore, if the cover crop is established later (e.g. in midSeptember) or growing conditions are sub-optimal after sowing (e.g. due to poor soil quality or weather conditions), then an initial application of fertiliser may be merited to promote growth and enable the cover crop to take up sufficient quantities of residual soil N (see supplementary Figure S2 which presents more recent results by the authors that demonstrate application of a starter fertiliser can reduce nitrate leaching losses). However, caution should be exercised as such action could increase diffuse pollution risk if cover crop roots are underdeveloped and unable to absorb this added fertiliser. This was not the case during this study, with the mild autumn of 2013 promoting vigorous growth of the oilseed radish and thus negating the need to apply additional fertiliser.

\subsection{Sub-catchment scale impacts}

Despite recording substantial reductions in soil water $\mathrm{NO}_{3}-\mathrm{N}$ during the cover crop period, it is clear from Figure 6 that there was no corresponding reduction in riverine $\mathrm{NO}_{3}-\mathrm{N}$ concentrations during the 2013/14 farm year. This is despite the cover crop trial area covering $20 \%$ (143 ha) of the catchment upstream of the bankside monitoring location (714 ha). A potential explanation for this apparent anomaly arises from previous research in the same catchment (Outram et al., 2016) which 
nutrient load in the River Blackwater over a three-year period. Outram et al. (2016) hypothesised that the catchment is in a state of biogeochemical stationarity, whereby as a consequence of decades of intensive fertiliser application, there exist legacy stores of nutrients within the catchment soils and sediments which act to buffer riverine nutrient concentrations from inter-annual changes in fertiliser application. By extension, we can apply the same principle here and hypothesise that nutrient reductions in soil water during the cover crop period do not immediately translate into reductions in riverine concentrations due to the mobilisation of nutrients from pre-existing legacy stores. It could potentially take 5-10 years or more for these nutrient stores to be depleted before major reductions instream are detected. Therefore, both repeated use of cover crops across a rotation and an extended monitoring period would be required to fully assess the effects of cover crops on river water quality at the sub-catchment scale.

\subsection{Cover crop management}

A number of practical management issues arose during the course of the trial. Prime among these were difficulties in destroying and incorporating the cover crop residues prior to the sowing of the subsequent spring bean crop in early 2014. The oilseed radish grew vigorously (up to $0.5 \mathrm{~m}$ in height) and was killed off with a glyphosphate herbicide in mid-January 2014 (Figure 2b). However, large quantities of fresh organic matter remained on the soil surface which proved difficult for the direct drill (Väderstad Seed Hawk) and shallow non-inversion tillage (Väderstad Rapid) machinery to handle. Slug populations were also considerably higher in the cover crop fields during both 2013/14 and $2014 / 15$, as accumulations of fresh plant material provided optimal feeding and breeding conditions, an effect reported elsewhere (Soane et al., 2012). This outcome necessitated additional applications of a molluscicide (metaldehyde) to the cover crop blocks, increasing the variable production costs (section 4.6). This also raised important concerns regarding pollution swapping, whereby adopting mitigation measures to reduce one type of pollution (i.e. $\mathrm{NO}_{3}$ leaching) inadvertently increases another source(i.e. pesticides) is inadvertently increased (Stevens and 
464 Quinton, 2009). Other agronomic problems encountered included enhanced pea and bean weevil damage to the following spring bean crop and damper soil conditions under the decaying cover crop residues which delayed spring cultivation operations by a few days.

\subsection{Farm economics}

For cover crops and non-inversion cultivation measures to be economically viable, these approaches need to be financially competitive with traditional farm practice (Posthumus et al., 2015). Table 6 summarises the economic performance of the three mitigation blocks for the 2013/14 farm year. The application and variable costs of establishing and managing the cover crop under direct drill

$472\left(£ 704 \mathrm{ha}^{-1}\right)$ and shallow non-inversion tillage $\left(£ 748 \mathrm{ha}^{-1}\right)$ were higher than conventional ploughing with winter fallow ( $\left.£ 589 \mathrm{ha}^{-1}\right)$. Previous research indicated that lower operational costs (e.g. fuel and labour) of non-inversion tillage systems could increase farm margins by $f 10-85 \mathrm{ha}^{-1}$ compared with conventional ploughing (Deasy et al., 2009; Morris et al., 2010). However, this study found that operational savings in the non-inversion tillage Blocks $P$ and $L$ were offset by increased costs associated with cover crop establishment, principally the purchasing of oilseed radish seed, application of starter $\mathrm{N}$ fertiliser and the application of additional molluscicide to control slugs. Nevertheless, higher yields for the 2013/14 spring bean crop in Blocks $L\left(6.24 t \mathrm{tha}^{-1}\right)$ and $P(6.55 \mathrm{t}$ ha $\left.{ }^{1}\right)$ compared with Block J (5.80 $\left.\mathrm{t} \mathrm{ha}^{-1}\right)$ resulted in only small differences in the overall gross margin between the cover crop/direct drill $\left(£ 731 \mathrm{ha}^{-1}\right)$, cover crop/shallow non-inversion tillage ( $₫ 758 \mathrm{ha}^{-1}$ ) and fallow/mouldboard ploughing $\left(£ 745 \mathrm{ha}^{-1}\right)$ systems. Yield increases in cash crops in the years following a winter cover crop have also been reported elsewhere (e.g. Stobart and Morris, 2014) demonstrating that farm productivity can be maintained or even enhanced whilst mitigating diffuse agricultural pollution. It is also important to recognise that cover crops can provide a range of additional ecosystem services aside from mitigating nutrient losses, such as carbon sequestration, $\mathrm{N}_{2} \mathrm{O}$ reduction and food production, which increase their environmental and socio-economic value 
provides good evidence to support the wider adoption of oilseed radish for mitigating diffuse nitrate pollution on UK arable farms.

491

\section{Conclusions}

492

To date, the majority of research into the efficacy of on-farm measures for mitigating diffuse agricultural pollution has come from controlled plot scale studies which typically fail to account for the impacts of measures upon crop yields, farm profit margins, catchment-scale nutrient losses, or the practicalities for the farmer of deploying such measures. Here, we have addressed these issues by assessing the impacts of cover crops and non-inversion tillage regimes at the farm-scale. The key findings were as follows:

(i) A winter oilseed radish cover crop reduced $\mathrm{NO}_{3}-\mathrm{N}$ leaching losses by $75-97 \%$ relative to fallow, but had no impact upon P losses;

(ii) Direct drilling and shallow non-inversion tillage were ineffective at reducing soil water $\mathrm{NO}_{3}-\mathrm{N}$ and $\mathrm{P}$ concentrations relative to conventional ploughing;

(iv) Despite covering $20 \%$ of the catchment, improvements in river water quality downstream of

(v) Higher operational costs associated with the establishment of cover crop and non-inversion tillage regimes were offset by increased yields in the subsequent cash crop, resulting in 

effectiveness of other cover crop varieties and crop mixtures at reducing arable nutrient losses, particularly in the UK, is highly recommended.

\section{Acknowledgements}

This research was funded by the UK Department for Environment, Food and Rural Affairs (Defra) under the Demonstration Test Catchments initiative (WQ0212/WQ0225/LM0304). ZH acknowledges support from the Kurdistan Regional Government and Human Capacity Development Program. The authors would like to thank the Salle Park Estate for their cooperation with the field trials and Carl Gudmundsson of Väderstad for technical advice and machinery support. Paul Brown of Frontier Agriculture Limited provided valuable advice in the choice of cover crop. We thank Liz Rix, Alina Mihailova, Kim Goodey, Tony Hinchliffe and Andy Hind for the laboratory analysis and Faye Outram, Jenny Stevenson, Simon Ellis, Nick Garrard and Steve Warnes for their fieldwork support. We are grateful to the editor and two anonymous reviewers whose constructive comments helped improve an earlier version of this manuscript.

\section{References}

Abdollahi, L., Munkholm, L.J., 2014. Tillage system and cover crop effects on soil quality: I. chemical, mechanical, and biological properties. Soil \& Water Management \& Conservation 78, 262-270. DOI: 10.2136/sssaj2013.07.0301

Aronsson, H., Torstensson, G., 1998. Measured and simulated availability and leaching of nitrogen associated with frequent use of catch crops. Soil Use and Management 14, 6-13. on $\mathrm{NO}_{3}-\mathrm{N}$ loss with subsurface drainage water. Transactions of the ASAE 45, 1789-1797. DOI: 
Bertol, I., Engel, F.L., Mafra, A.L., Bertol, O.J., Ritter, S.R., 2007. Phosphorus, potassium and organic carbon concentrations in runoff water and sediments under different soil tillage systems during soybean growth. Soil \& Tillage Research 94, 142-150. DOI: 10.1016/j.still.2006.07.008.

Beaudoin, N., Saad, J.K., Van Laethem, C.V., Machet, J.M., Maucorps, J., Mary, B., 2005. Nitrate leaching in intensive agriculture in Northern France: effect of farming practices, soils and crop rotations. Agriculture, Ecosystems and Environment 111, 292-310. DOI: 10.1016/j.agee.2005.06.006.

Bremner, J.M., 1965. Nitrogen availability index, in: Black, C. (Ed.), Methods of soil analysis: part 2. American Society of Agronomy, Madison, WI, pp. 1324-1345.

Catt, J.A., Howse, K.R., Christian, D.G., Lane, P.W., Harris, G.L., Goss, M.J., 1998. Strategies to decrease nitrate leaching in the Brimstone Farm Experiment, Oxfordshire, UK, 1988-1993: the effects of winter cover crops and unfertilised grass leys. Plant and Soil 203, 57-69.

Dabney, S.M., Delgado, J.A., Reeves, D.W., 2001. Using winter cover crops to improve soil and water quality. Communications in Soil Science and Plant Analysis 32, 1221-1250. DOI: 10.1081/CSS-100104110.

Deasy, C., Quinton, J.N., Silgram, M., Bailey, A.P., Jackson, B., Stevens, C.J., 2009. Mitigation options for sediment and phosphorus loss from winter-sown arable crops. Journal of Environmental Quality 38, 21212130. DOI: $10.2134 /$ jeq2009.0028.

Deasy, C., Quinton, J.N., Silgram, M., Bailey, A.P., Jackson, B., Stevens, C.J., 2010. Contributing understanding of mitigation options for phosphorus and sediment to a review of the efficacy of contemporary agricultural stewardship measures. Agricultural Systems 103, 105-109. DOI: 10.1016/j.agsy.2009.10.003.

DEFRA, 2015. England natural environment indicators. Department for Environment, Food and Rural Affairs, Nobel House, London, UK, pp. 63.

Dodds, W.K., Bouska, W.W., Eitzmann, J.L., Pilger, T.J., Pitts, K.L., Riley, A.J., Schloesser, J.T., Thornbrugh, D.J., 2009. Eutrophication of U.S. freshwaters: analysis of potential economic damages. Environmental Science and Technology 43, 12-19. DOI: 10.1021/es801217q.

Hilton, J., O'Hare, M., Bowes, M.J., Jones, J.I., 2006. How green is my river? A new paradigm of eutrophication in rivers. Science of the Total Environment 365, 66-83. DOI:10.1016/j.scitotenv.2006.02.055. 
561

Hiscock, K.M., 1993. The influence of pre-Devensian glacial deposits on the hydrogeochemistry of the chalk aquifer system of north Norfolk, UK. Journal of Hydrology 144, 335-369. DOI: 10.1016/00221694(93)90179-D.

Holland, J.M., 2004. The environmental consequences of adopting conservation tillage in Europe: reviewing the evidence. Agriculture, Ecosystems and Environment 103, 1-25. DOI: 10.1016/j.agee.2003.12.018.

Hooker, K.V., Coxon, C.E., Hackett, R., Kirwan, L.E., O’Keeffe, E., Richards, K.G., 2008. Evaluation of cover crop and reduced cultivation for reducing nitrate leaching in Ireland. Journal of Environmental Quality 37, 138145. DOI: $10.2134 /$ jeq2006.0547.

Kay, P., Edwards, A.C., Foulger, M., 2009. A review of the efficacy of contemporary agricultural stewardship measures for ameliorating water pollution problems of key concern to the UK water industry. Agricultural Systems 99, 67-75. DOI: 10.1016/j.agsy.2008.10.006.

Kronvang, B., Jeppesen, E., Conley, D.J., Søndergaard, M., Larsen, S.E., Ovesen, N.B., Carstensen, J., 2005. Nutrient pressures and ecological responses to nutrient loading reductions in Danish streams, lakes and coastal waters. Journal of Hydrology 304, 274-288. DOI: 10.1016/j.jhydrol.2004.07.035.

Lal, R., Reicosky, D.C., Hanson, J.D., 2007. Evolution of the plow over 10,000 years and the rationale for no-till farming. Soil \& Tillage Research 93, 1-12. DOI: 10.1016/j.still.2006.11.004.

Lewis, M.A., 2011. Borehole drilling and sampling in the Wensum Demonstration Test Catchment. British Geological Survey Commissioned Report, CR/11/162, pp. 38.

Lu, Y.C., Watkins, B., Teasdale, J.R., Abdul-Baki, A.A., 2000. Cover crops in sustainable food production. Food Reviews International 16, 121-157. DOI: 10.1081/FRI-100100285.

Macdonald, A.J., Poulton, P.R., Howe, M.T., Goulding, K.W.T., Powlson, D.S., 2005. The use of cover crops in cereal-based cropping systems to control nitrate leaching in SE England. Plant and Soil 273, 355-373. DOI: 10.1007/s11104-005-0193-3.

McGonigle, D.F., Burke, S.P., Collins, A.L., Gartner, R., Haft, M.R., Harris, R.C., Haygarth, P.M., Hedges, M.C., Hiscock, K.M., Lovett, A.A., 2014. Developing Demonstration Test Catchments as a platform for transdisciplinary land management research in England and Wales. Environmental Science: Processes \& Impacts 16, 1618-1628. DOI: 10.1039/c3em00658a. 
Meteorological Office, 2016. UK climate averages: Reepham 1981-2010. Meteorological Office, Exeter. Online: http://www.metoffice.gov.uk/public/weather/climate/u12gmt1fz.

Morris, N.L., Miller, P.C.H., Orson, J.H., Froud-Williams, R.J., 2010. The adoption of non-inversion tillage systems in the United Kingdom and the agronomic impact on soil, crops and the environment - a review. Soil \& Tillage Research 108, 1-15. DOI: 10.1016/j.still.2010.03.004.

Némery, J., Garnier, J., 2016. Biogeochemistry: The fate of phosphorus. Nature Geoscience. DOI: 10.1038/ngeo2702.

Outram, F.N., Lloyd, C.E.M., Jonczyk, J., Benskin, C.McW.H., Grant, F., Perks, M.T., Deasy, C., Burke, S.P., Collins, A.L., Freer, J., Haygarth, P.M., Hiscock, K.M., Johnes, P.J., Lovett, A.A., 2014. High-frequency monitoring of nitrogen and phosphorus response in three rural catchments to the end of the 2011-2012 drought in England. Hydrol. Earth Syst. Sci. 18, 3429-3448. DOI: 10.5194/hess-18-3429-2015.

Outram, F.N., Cooper, R.J., Sünnenberg, G., Hiscock, K.M., Lovett, A.A., 2016. Antecedent conditions, hydrological connectivity and anthropogenic inputs: factors affecting nitrate and phosphorus transfers to agricultural headwater streams. Science of the Total Environment 545-546, 184-199. DOI: 10.1016/j.scitotenv.2015.12.025.

Posthumus, H., Deeks, L.K., Rickson, R.J., Quinton, J.N., 2015. Costs and benefits of erosion control measures in the UK. Soil Use and Management 31, 16-33. DOI: 10.1111/sum.12057.

Premrov, A., Coxon, C.E., Hackett, R., Kirwan, L., Richards, K.G., 2014. Effects of over-winter green cover on soil solution nitrate concentrations beneath tillage land. Science of the Total Environment 470-471, 967-974. DOI: 10.1016/j.scitotenv.2013.10.057.

Pretty, J.N., Brett, C., Gee, D., Hine, R.E., Mason, C.F., Morison, J.I.L., Raven, H., Rayment, M.D., van der Bijl, G., 2000. An assessment of the total external costs of UK agriculture. Agricultural Systems 65, 113-136. DOI: 10.1016/S0308-521X(00)00031-7.

Pretty, J.N., Mason, C.F., Nedwell, D.B., Hine, R.E., Leaf, S., Dils, R., 2003. Environmental costs of freshwater eutrophication in England and Wales. Environmental Science and Technology 37, 201-208. DOI: 10.1021/es020793k. 
Puget, P., Lal, R., 2005. Soil organic carbon and nitrogen in a Mollisol in central Ohio as affected by tillage and land use. Soil \& Tillage Research 80, 201-213. DOI: 10.1016/j.still.2004.03.018.

Rawlins, B.G., Wragg, J., Lark, R.M., 2013. Application of a novel method for soil aggregate stability measurement by laser granulometry with sonication. European Journal of Soil Science 64, 92-103. DOI.10.1111/ejss.12017

Schipanski, M.E., Barbercheck, M., Douglas, M.R., Finney, D.M., Haider, K., Kaye, J.P., Kemanian, A.R., Mortensen, D.A., Ryan, M.R., Tooker, J., White, C., 2014. A framework for evaluating ecosystem services provided by cover crops in agroecosystems. Agricultural Systems 125, 12-22. DOI: 10.1016/j.agsy.2013.11.004.

Skinner, J.A., Lewis, K.A., Bardon, K.S., Tucker, P., Catt, J.A., Chambers, B.J., 1997. An overview of the environmental impact of agriculture in the U.K. Journal of Environmental Management 50, 111-128.

Smith, V.H., Tilman, G.D., Nekola, J.C., 1999. Eutrophication: impacts of excess nutrient inputs on freshwater, marine, and terrestrial ecosystems. Environmental Pollution 100, 179-196. DOI:10.1016/S02697491(99)00091-3.

Smith, V.H., Schindler, D.W., 2009. Eutrophication science: where do we go from here? Trends in Ecology and Evolution 24, 201-207. DOI: 10.1016/j.tree.2008.11.009.

Snapp, S.S., Swinton, S.M., Labarta, R., Mutch, D., Black, J.R., Leep, R., Nyiraneza, J., O’Neil, K., 2005. Evaluating cover crops for benefits, costs and performance within cropping system niches. Agronomy Journal 97, 322332.

Soane, B.D., Ball, B.C., Arvidsson, J., Basch, G., Moreno, F., Roger-Estrade, J., 2012. No-till in northern, western and south-western Europe: A review of problems and opportunities for crop production and the environment. Soil \& Tillage Research 118, 66-87. DOI: 10.1016/j.still.2011.10.015.

Stevens, C.J., Quinton, J.N., 2009. Diffuse pollution swapping in arable agricultural systems. Critical Reviews in Environmental Science and Technology 39, 478-520. DOI: 10.1080/10643380801910017.

Stobart, R., Morris, N.L., 2014. The impact of cover crops on yield and soils in the New Farming Systems programme. Aspects of Applied Biology 127, 223-232. 
640 Tebrügge, F., Düring, R.A., 1999. Reducing tillage intensity - a review of results from a long-term study in 641 Germany. Soil \& Tillage Research 53, 15-28.

642 Thomsen, I.K., Christensen, B.T., 2004. Yields of wheat and soil carbon and nitrogen contents following long643 term incorporation of barley straw and ryegrass catch crops. Soil Use Management 20, 432-438. DOI: $644 \quad$ 10.1111/j.1475-2743.2004.tb00393.x.

645 Tonitto, C., David, M.B., Drinkwater, L.E., 2006. Replacing bare fallows with cover crops in fertilizer-intensive 646 cropping systems: A meta-analysis of crop yield and N dynamics. Agriculture, Ecosystems and Environment 647 112, 58-72. DOI: 10.1016/j.agee.2005.07.003.

648 Valkama, E., Lemola, R., Känkänen, H., Turtola, E., 2015. Meta-analysis of the effects of undersown catch crops 649 on nitrogen leaching loss and grain yields in the Nordic countries. Agriculture, Ecosystems and Environment 650 203, 93-101. DOI: 10.1016/j.agee.2015.01.023.

651 Wensum Alliance, 2016. River Wensum Demonstration Test Catchment Project. Online. 652 http://www.wensumalliance.org.uk/.

653

654

655

656

657

658

659

660

661

662

663

664 


\section{Figures}

666
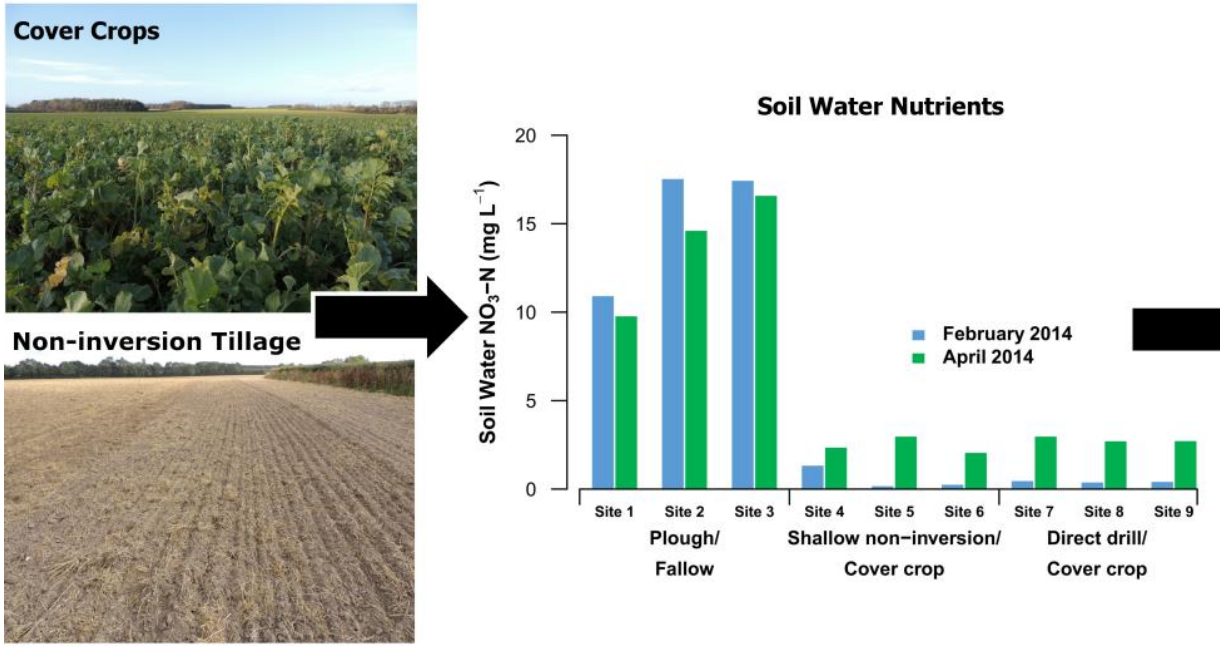

Riverine Nutrients

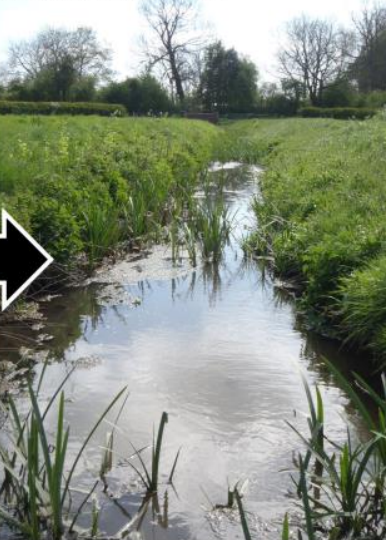

667 Graphical Abstract: The impact of cover crops and non-inversion tillage regimes on soil and riverine nutrient concentrations is assessed at the farm-scale.

669

670 


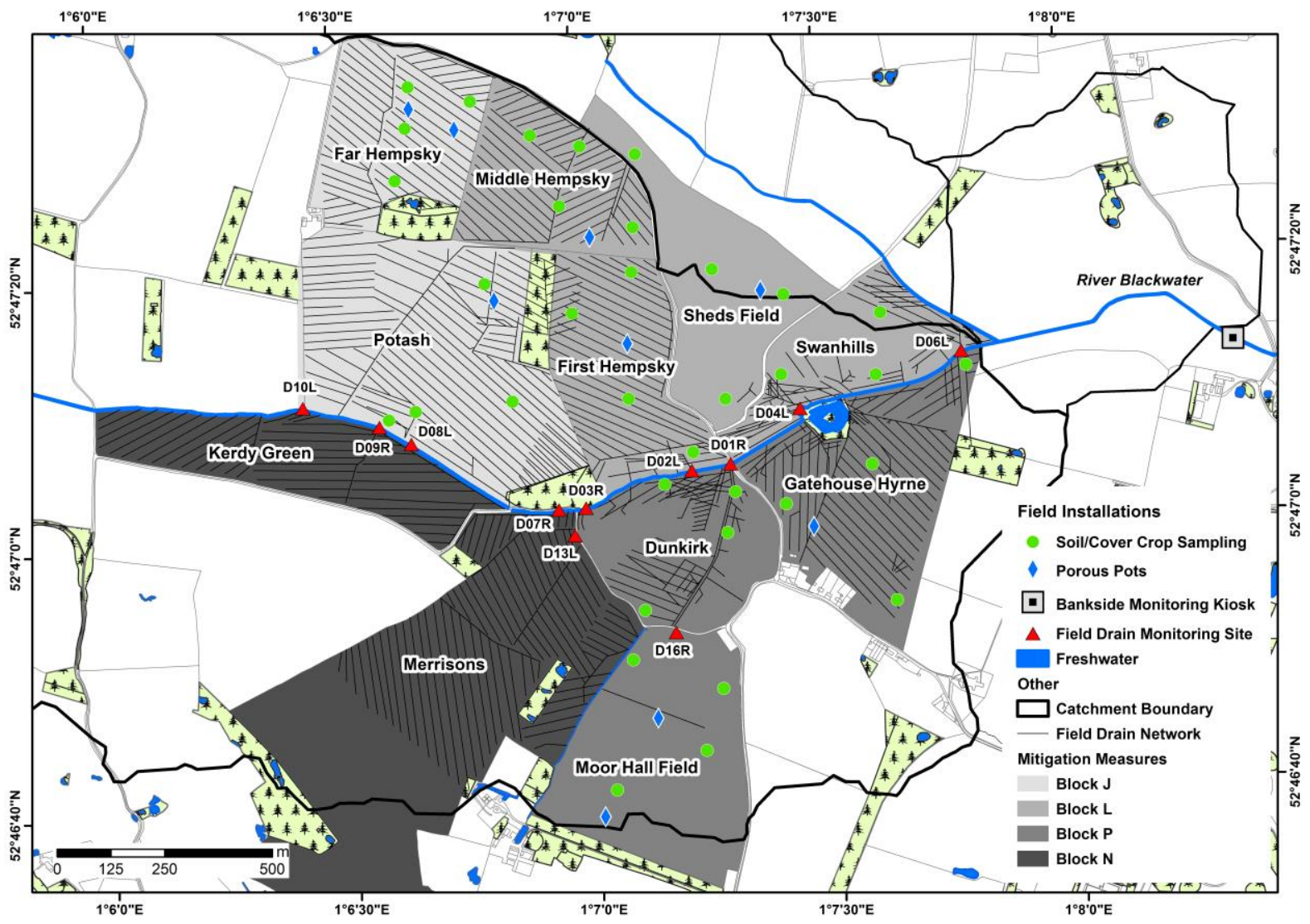

672 Figure 1: Map of the Salle Park Estate mitigation measures blocks in the River Blackwater sub-

673 catchment, Norfolk, UK, showing the locations of field installations and sampling points. 

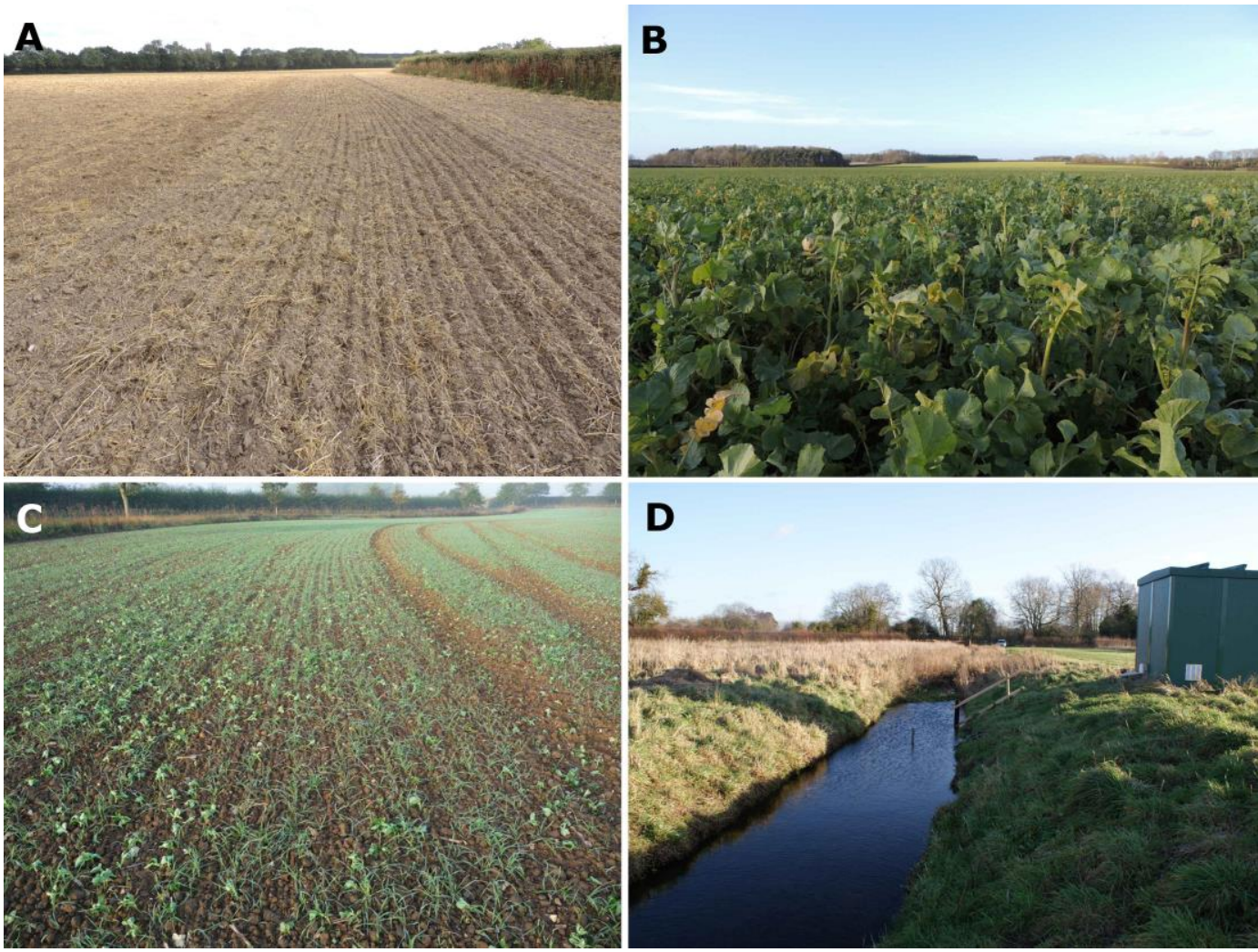

D

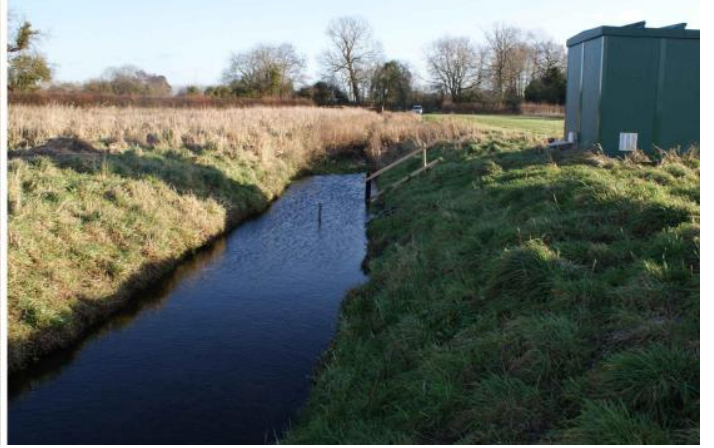

676 Figure 2: Images of the Salle Park Estate. (A) Direct drilled oilseed radish on Sheds Field in September

677 2013. Crop residues from the previous spring barley crop can be seen on the surface; (B) Oilseed

678 radish cover crop on Dunkirk field in February 2014; (C) Winter wheat on the shallow non-inversion

679 tillage Dunkirk field in November 2014. Spring bean volunteers can be seen emerging through the

680 wheat; (D) Bankside monitoring kiosk on the River Blackwater downstream of the mitigation

681 measures trial area. River channel is $2.5 \mathrm{~m}$ wide. 


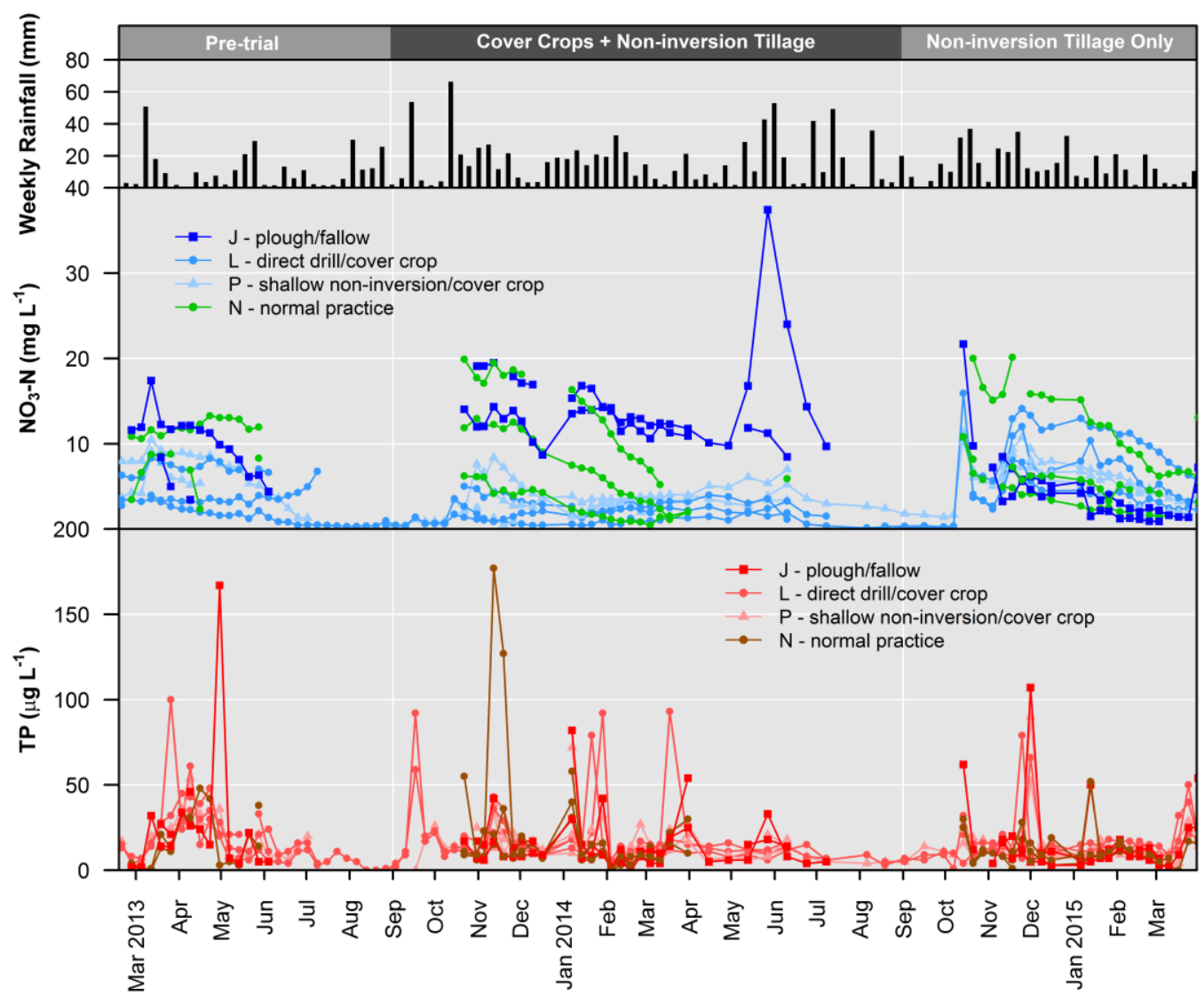

684 Figure 3: Field drain $\mathrm{NO}_{3}-\mathrm{N}$ and TP concentrations measured in Blocks J, L, $\mathrm{P}$ and $\mathrm{N}$ between March 6852013 and March 2015.

686 

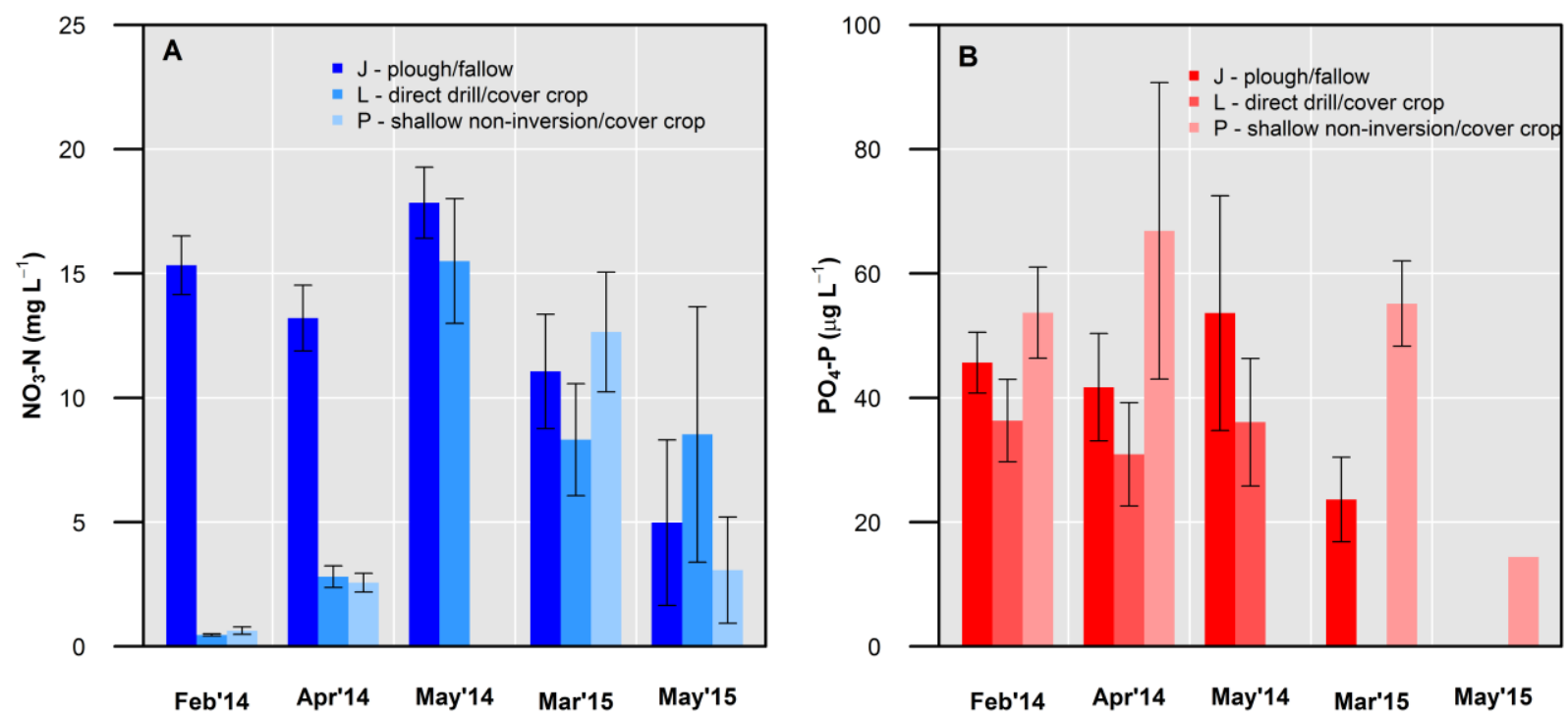

Figure 4: Porous pot (A) $\mathrm{NO}_{3}-\mathrm{N}$ and (B) $\mathrm{PO}_{4}-\mathrm{P}$ concentrations measured in Blocks $\mathrm{J}, \mathrm{L}$ and $\mathrm{P}$ on five sampling occasions. Error bars represent one standard error.

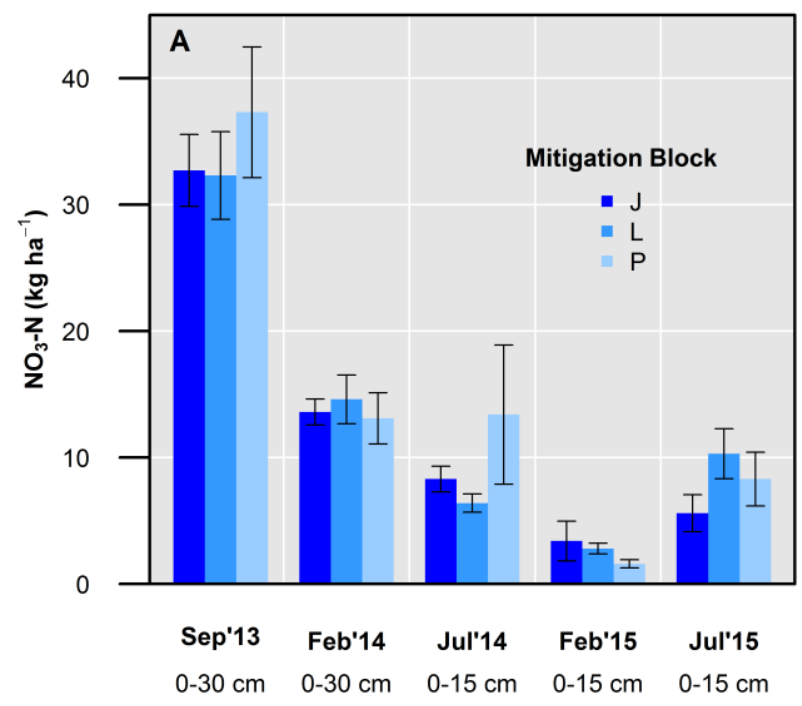

692

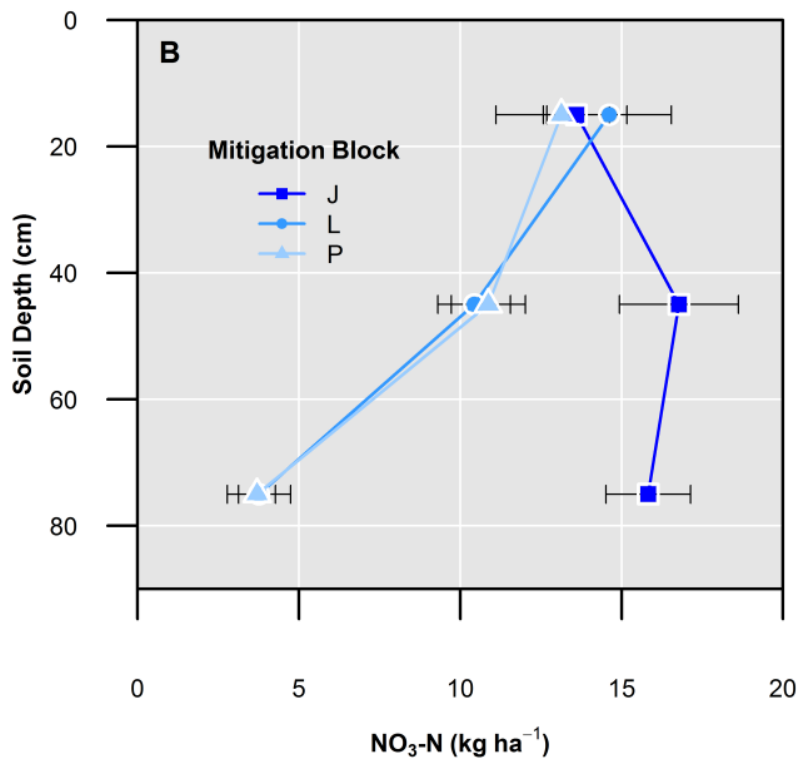

693 Figure 5: (A) Mean topsoil $\mathrm{NO}_{3}-\mathrm{N}$ concentrations recorded in the three mitigation measures blocks on five sampling occasions; (B) Mean soil $\mathrm{NO}_{3}-\mathrm{N}$ depth profiles recorded in February 2014. Error bars represent one standard error. 


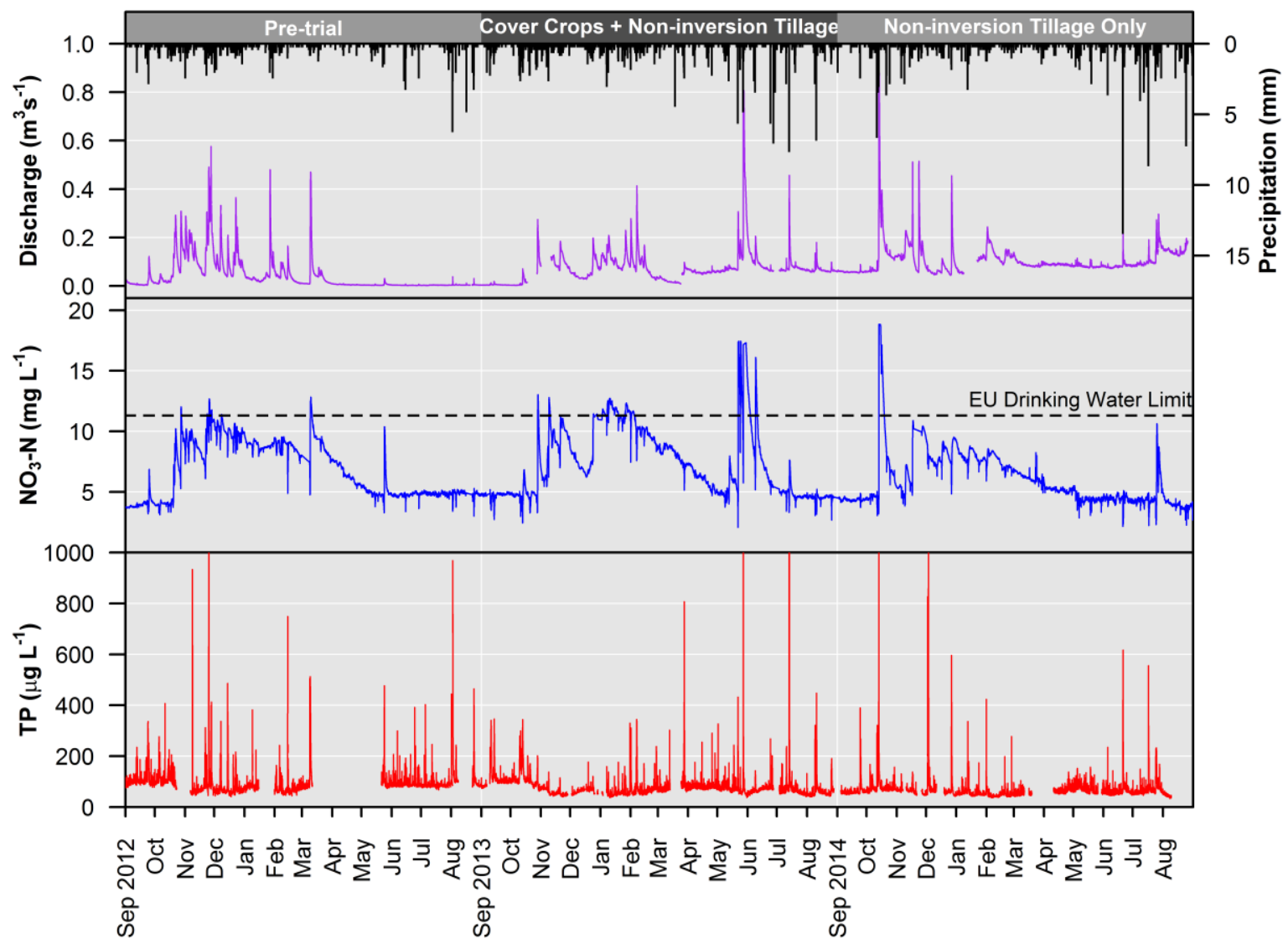

Figure 6: High-frequency (30 min) hydrochemical data for the River Blackwater recorded between 


\section{Tables}

714

715 Table 1: Summary of the crop types and cultivation methods employed in the mitigation measures

716 blocks during three farm years. $\mathrm{WW}=$ winter wheat; $\mathrm{WBAR}=$ winter barley; SBAR = spring barley; SB

717 = spring beans; OR CC = oilseed radish cover crop; OSR = winter oilseed rape. Monitored field drains

718 also listed.

\begin{tabular}{|c|c|c|c|c|c|c|c|c|c|c|}
\hline Field Name & Block & Soil Type & $\begin{array}{l}\text { Size } \\
\text { (ha) }\end{array}$ & $\begin{array}{l}\text { 2012/13 } \\
\text { Crop }\end{array}$ & $\begin{array}{l}\text { 2013/14 } \\
\text { Crop }\end{array}$ & $\begin{array}{l}\text { Starter } \\
\text { Fertiliser }\end{array}$ & $\begin{array}{l}\text { 2013/14 } \\
\text { Cultivation }\end{array}$ & $\begin{array}{l}\text { 2014/15 } \\
\text { Crop }\end{array}$ & $\begin{array}{l}\text { 2014/15 } \\
\text { Cultivation }\end{array}$ & $\begin{array}{l}\text { Field } \\
\text { Drains }\end{array}$ \\
\hline Potash & $\mathrm{J}$ & Clay loam & 28.4 & WW & SB & - & Plough & WW & Plough & D08L, D10L \\
\hline Far Hempsky & J & Sand clay loam & 13.3 & SBAR & SB & - & Plough & WW & Plough & - \\
\hline Gatehouse Hyrne & $\mathrm{P}$ & Clay loam & 18.8 & SBAR & $\mathrm{OR} C \mathrm{C} / \mathrm{SB}$ & $\mathrm{Y}$ & $\begin{array}{l}\text { Shallow non- } \\
\text { inversion }\end{array}$ & WW & $\begin{array}{l}\text { Shallow non- } \\
\text { inversion }\end{array}$ & - \\
\hline Moor Hall Field & $\mathrm{P}$ & Sandy clay loam & 20.2 & SBAR & $\mathrm{OR} C \mathrm{CC} \mathrm{SB}$ & $\mathrm{N}$ & $\begin{array}{l}\text { Shallow non- } \\
\text { inversion }\end{array}$ & WW & $\begin{array}{l}\text { Shallow non- } \\
\text { inversion }\end{array}$ & D16R \\
\hline Dunkirk & $\mathrm{P}$ & Sandy clay loam & 12.9 & WW & $\mathrm{OR} C \mathrm{CC} \mathrm{SB}$ & $\mathrm{Y}$ & $\begin{array}{l}\text { Shallow non- } \\
\text { inversion }\end{array}$ & WW & $\begin{array}{l}\text { Shallow non- } \\
\text { inversion }\end{array}$ & D01R, D03R \\
\hline Middle Hempsky & L & Clay loam & 12.6 & SBAR & OR CC/SB & $\mathrm{N}$ & Direct drill & WW & Direct drill & - \\
\hline First Hempsky & L & Sandy clay loam & 14.6 & SBAR & $\mathrm{OR} C \mathrm{C} / \mathrm{SB}$ & $\mathrm{Y}$ & Direct drill & WW & Direct drill & $\mathrm{D} 02 \mathrm{~L}$ \\
\hline Sheds Field & L & Sandy loam & 14.8 & SBAR & $\mathrm{OR} C \mathrm{C} / \mathrm{SB}$ & $\mathrm{Y}$ & Direct drill & WW & Direct drill & - \\
\hline Swanhills & L & Sandy loam & 11.1 & SBAR & $\mathrm{OR} C \mathrm{CC} \mathrm{SB}$ & $\mathrm{Y}$ & Direct drill & WW & Direct drill & D04L, D06L \\
\hline Merrisons & $\mathrm{N}$ & Clay loam & 48.7 & SB & WW & - & Plough & WBAR & Plough & D07R, D13L \\
\hline Kerdy Green & $\mathrm{N}$ & Clay loam & 14.4 & WBAR & OSR & - & Plough & WW & Plough & D09R \\
\hline
\end{tabular}

719

720

721

722

723

724

725

726

727 
Table 2: Field drain flows, nutrient concentrations and loads recorded under each mitigation measure block between March 2013 and March 2015. Values presented as means \pm one standard deviation. Asterisks indicate $t$-test significant differences $\left({ }^{*}=p<0.05,{ }^{* *}=p<0.01\right)$ from control Block J.

\begin{tabular}{|c|c|c|c|c|}
\hline Parameter & Block & $\begin{array}{r}\text { Pre-trial } \\
(2012 / 13)\end{array}$ & $\begin{array}{r}\text { Cover crops + } \\
\text { non-inversion } \\
\text { tillage } \\
(2013 / 14) \\
\end{array}$ & $\begin{array}{r}\text { Non-inversion tillage } \\
\text { only } \\
(2014 / 15)\end{array}$ \\
\hline \multirow{4}{*}{$\begin{array}{l}\text { Flow } \\
\left(\mathrm{L} \mathrm{s}^{-1}\right)\end{array}$} & $\mathrm{J}$ & $0.04 \pm 0.04$ & $0.19 \pm 0.19$ & $0.19 \pm 0.17$ \\
\hline & $P$ & $0.07 \pm 0.11$ & $0.17 \pm 0.22$ & $0.26 \pm 0.41$ \\
\hline & L & $0.04 \pm 0.03$ & $0.07 \pm 0.06 * *$ & $0.08 \pm 0.05^{* *}$ \\
\hline & N & $0.06 \pm 0.07$ & $0.23 \pm 0.21$ & $0.26 \pm 0.24$ \\
\hline \multirow{4}{*}{$\begin{array}{c}\mathrm{NO}_{3}-\mathrm{N} \text { concentration } \\
\left(\mathrm{mg} \mathrm{N} \mathrm{L}^{-1}\right)\end{array}$} & J & $9.6 \pm 3.6$ & $14.0 \pm 4.6$ & $4.3 \pm 3.7$ \\
\hline & $\mathrm{P}$ & $6.4 \pm 2.5$ & $3.5 \pm 1.6^{* *}$ & $5.5 \pm 2.5$ \\
\hline & $\mathrm{L}$ & $5.5 \pm 2.2$ & $1.8 \pm 1.1^{* *}$ & $6.2 \pm 3.9$ \\
\hline & $\mathrm{N}$ & $10.0 \pm 3.0$ & $7.7 \pm 5.7^{* *}$ & $7.6 \pm 5.0^{*}$ \\
\hline \multirow{4}{*}{$\begin{array}{l}\mathrm{NO}_{3}-\mathrm{N} \text { load } \\
\left(\mathrm{kg} \mathrm{N} \mathrm{ha}^{-1} \mathrm{a}^{-1}\right)\end{array}$} & J & $2.2 \pm 5.8$ & $71.9 \pm 160.4$ & $39.2 \pm 137.6$ \\
\hline & $\mathrm{P}$ & $4.6 \pm 14.7$ & $13.8 \pm 24.2^{* *}$ & $102.1 \pm 219.9 *$ \\
\hline & $\mathrm{L}$ & $13.5 \pm 26.7^{* *}$ & $15.3 \pm 26.6^{* *}$ & $47.0 \pm 53.4$ \\
\hline & N & $0.9 \pm 3.2$ & $9.0 \pm 18.4^{* *}$ & $15.7 \pm 31.8$ \\
\hline \multirow{4}{*}{$\begin{array}{l}\text { TP concentration } \\
\left(\mu \mathrm{P} \mathrm{P} \mathrm{L}^{-1}\right)\end{array}$} & J & $26 \pm 37$ & $15 \pm 15$ & $16 \pm 20$ \\
\hline & $\mathrm{P}$ & $21 \pm 14$ & $14 \pm 10$ & $14 \pm 12$ \\
\hline & $\mathrm{L}$ & $22 \pm 18$ & $16 \pm 17$ & $15 \pm 12$ \\
\hline & $\mathrm{N}$ & $16 \pm 15$ & $17 \pm 28$ & $11 \pm 9$ \\
\hline \multirow{4}{*}{$\begin{array}{c}\text { TP load } \\
\left(\mathrm{kg} \mathrm{P} \mathrm{ha}^{-1} \mathrm{a}^{-1}\right)\end{array}$} & J & $0.02 \pm 0.05$ & $0.19 \pm 0.73$ & $0.20 \pm 0.50$ \\
\hline & $P$ & $0.02 \pm 0.06$ & $0.08 \pm 0.24$ & $0.26 \pm 0.65$ \\
\hline & L & $0.13 \pm 0.44 *$ & $0.13 \pm 0.21$ & $0.12 \pm 0.17$ \\
\hline & $\mathrm{N}$ & $0.01 \pm 0.01$ & $0.03 \pm 0.10$ & $0.03 \pm 0.08 *$ \\
\hline
\end{tabular}

732

733 
Table 3: Summary of the topsoil nutrient analyses for the mitigation measures blocks. Values presented as averages \pm one standard deviation. Asterisks indicate $t$-test significant differences $\left(^{*}=\right.$ $p<0.05,{ }^{* *}=p<0.01$ ) from control Block J.

\begin{tabular}{|c|c|c|c|c|c|c|}
\hline Sampling Date & $\begin{array}{l}\text { Mitigation } \\
\text { Period }\end{array}$ & $\begin{array}{l}\text { Mitigation } \\
\text { Block }\end{array}$ & $\begin{array}{r}\text { Nitrate-N } \\
\left(\mathbf{k g ~ N ~ h a}^{-1}\right)\end{array}$ & $\begin{array}{r}\text { Phosphorus } \\
\left(\mathrm{kg} \mathrm{P} \mathrm{ha}^{-1}\right)\end{array}$ & $\begin{array}{l}\text { Potassium } \\
\left(\mathrm{kg} \mathrm{K} \mathrm{ha}^{-1}\right)\end{array}$ & $\begin{array}{r}\text { Organic Matter } \\
\text { (\%) }\end{array}$ \\
\hline \multirow{3}{*}{$\begin{array}{l}\text { September } 2013 \\
\quad(0-30 \mathrm{~cm})\end{array}$} & \multirow{3}{*}{ Pre-trial } & $\mathrm{J}$ & $32.7 \pm 8.1$ & $96.4 \pm 26.0$ & $498.4 \pm 105.5$ & $2.0 \pm 0.4$ \\
\hline & & $P$ & $37.3 \pm 17.9$ & $132.0 \pm 47.9 *$ & $557.5 \pm 157.5$ & $1.7 \pm 0.4$ \\
\hline & & L & $32.3 \pm 13.9$ & $142.5 \pm 51.7^{* *}$ & $483.1 \pm 101.1$ & $1.5 \pm 0.4$ \\
\hline \multirow{3}{*}{$\begin{array}{l}\text { February } 2014 \\
\qquad(0-30 \mathrm{~cm})\end{array}$} & Cover crops & J & $13.6 \pm 2.9$ & $80.6 \pm 23.7$ & $426.6 \pm 115.3$ & $2.0 \pm 0.6$ \\
\hline & + non- & $P$ & $13.1 \pm 7.0$ & $130.8 \pm 43.5^{* *}$ & $687.4 \pm 138.1^{* *}$ & $1.9 \pm 0.6$ \\
\hline & $\begin{array}{l}\text { inversion } \\
\text { tillage }\end{array}$ & L & $14.6 \pm 7.7$ & $131.2 \pm 41.6^{* *}$ & $648.1 \pm 153.2^{* *}$ & $1.6 \pm 0.5$ \\
\hline \multirow{6}{*}{$\begin{array}{l}\text { February } 2015 \\
(0-15 \mathrm{~cm})\end{array}$} & Cover crops & J & $8.3 \pm 2.9$ & - & - & - \\
\hline & + non- & $P$ & $13.4 \pm 19.0$ & - & - & - \\
\hline & $\begin{array}{l}\text { inversion } \\
\text { tillage }\end{array}$ & L & $6.4 \pm 2.9$ & - & - & - \\
\hline & Non- & $\mathrm{J}$ & $3.4 \pm 4.4$ & $46.0 \pm 16.3$ & $240.5 \pm 71.1$ & $2.1 \pm 0.6$ \\
\hline & inversion & $P$ & $1.6 \pm 1.1$ & $62.6 \pm 25.6$ & $306.0 \pm 57.2^{*}$ & $1.8 \pm 0.5$ \\
\hline & tillage only & L & $2.8 \pm 1.7$ & $74.2 \pm 29.7^{* *}$ & $352.7 \pm 107.1^{* *}$ & $1.7 \pm 0.5$ \\
\hline \multirow{3}{*}{$\begin{array}{l}\text { July } 2015 \\
(0-15 \mathrm{~cm})\end{array}$} & Non- & $\mathrm{J}$ & $5.6 \pm 4.2$ & $54.0 \pm 22.5$ & $192.6 \pm 72.7$ & $2.1 \pm 0.6$ \\
\hline & inverison & $P$ & $8.3 \pm 7.3$ & $60.9 \pm 24.9$ & $249.7 \pm 49.7$ & $1.9 \pm 0.5$ \\
\hline & tillage only & L & $10.3 \pm 7.9$ & $77.4 \pm 30.3^{*}$ & $292.0 \pm 124.9^{*}$ & $1.8 \pm 0.6$ \\
\hline
\end{tabular}

748 Table 4: Nutrient analysis of the oilseed radish cover crop undertaken in January 2014. Values presented as averages \pm one standard deviation.

\begin{tabular}{llrr}
\hline Parameter & Cover crop & With Starter Fertiliser & Without Starter Fertiliser \\
\hline Nitrogen content & Leaf & $65.8 \pm 12.6$ & $57.3 \pm 3.3$ \\
$\left(\mathrm{~kg} \mathrm{~N} \mathrm{ha}^{-1}\right)$ & Root & $13.6 \pm 5.5$ & $12.3 \pm 1.7$ \\
& Leaf + root & $79.4 \pm 13.7$ & $69.6 \pm 3.7$ \\
Phosphorus content & Leaf & $7.4 \pm 1.7$ & $6.6 \pm 0.5$ \\
$\left(\mathrm{~kg} \mathrm{P} \mathrm{ha}^{-1}\right)$ & Root & $4.1 \pm 1.2$ & $4.9 \pm 0.7$ \\
& Leaf + root & $11.5 \pm 2.0$ & $11.5 \pm 0.9$ \\
Potassium content & Leaf & $66.7 \pm 13.8$ & $53.6 \pm 4.6$ \\
$\left(\mathrm{~kg} \mathrm{~K}^{-1}\right)$ & Root & $23.2 \pm 4.5$ & $23.2 \pm 2.2$ \\
& Leaf + root & $90.0 \pm 14.5$ & $76.8 \pm 5.1$ \\
Dry matter & Leaf & $2.2 \pm 0.3$ & $1.9 \pm 0.2$ \\
$\left(\mathrm{t} \mathrm{ha}{ }^{-1}\right)$ & Root & $0.6 \pm 0.1$ & $0.7 \pm 0.1$ \\
& Leaf + root & $2.8 \pm 0.3$ & $2.6 \pm 0.2$ \\
\hline
\end{tabular}


754 Table 5: February 2014 nitrogen balance for the cover crop fields applied with starter fertiliser

755 compared to those without a starter fertiliser. Values reported as averages \pm one standard deviation.

\begin{tabular}{lllrrr}
\hline Parameter & Type & Units & With Fertiliser & Without Fertiliser & N Balance \\
\hline Inputs & Applied fertiliser & $\mathrm{kg} \mathrm{N} \mathrm{ha}^{-1}$ & 30.0 & 0.0 & +30.0 \\
Outputs & Oilseed radish & $\mathrm{kg} \mathrm{N} \mathrm{ha}^{-1}$ & $79.4 \pm 13.7$ & $69.6 \pm 3.7$ & -9.8 \\
\cline { 3 - 5 } & & & $15.0 \pm 8.1$ & $\mathbf{N e t}$ & $+\mathbf{2 0 . 2}$ \\
\cline { 3 - 5 } Residuals & Soil 0-30 cm & $\mathrm{kg} \mathrm{NO}_{3}-\mathrm{N} \mathrm{ha}^{-1}$ & $11.5 \pm 4.7$ & $8.4 \pm 1.1$ & +3.6 \\
& Soil 30-60 cm & $\mathrm{kg} \mathrm{NO}_{3}-\mathrm{N} \mathrm{ha}^{-1}$ & & $3.0 \pm 2.6$ & +1.0 \\
& Soil 60-90 cm & $\mathrm{kg} \mathrm{NO}_{3}-\mathrm{N} \mathrm{ha}^{-1}$ & $4.0 \pm 3.4$ & $0.3 \pm 0.2$ & +0.5 \\
\hline
\end{tabular}

756

757 Table 6: Summary of the economic performance of the three mitigation measures blocks during the 758 2013/14 farm year.

\begin{tabular}{lrrr}
\hline \multirow{2}{*}{ Profit/Cost } & \multicolumn{3}{c}{ Mitigation Measure Block $\left(\mathbf{f} \mathbf{~ h a ~}^{-\mathbf{1}}\right)$} \\
& $\mathbf{J}$ & $\mathbf{L}$ & $\mathbf{P}$ \\
\hline Yield $\left(\mathrm{t} \mathrm{ha}^{-1}\right)$ & 5.80 & 6.24 & 6.55 \\
Income* & 1334 & 1435 & 1506 \\
Establishment costs & 96 & 67 & 128 \\
Application costs & 90 & 120 & 120 \\
Harvesting costs & 85 & 85 & 85 \\
Variable costs & 318 & 432 & 415 \\
Total Costs & 589 & 704 & 748 \\
\hline Gross margin & $\mathbf{7 4 5}$ & $\mathbf{7 3 1}$ & $\mathbf{7 5 8}$ \\
\hline *Assuming $\mathrm{f} 230 \mathrm{t}^{-1}$ & & &
\end{tabular}

759 